\begin{tabular}{|c|c|c|c|}
\hline Article Info & RESEARCH ARTICLE & ARAŞTIRMA MAKALESİ & \\
\hline Title of Article & \multicolumn{2}{|c|}{$\begin{array}{c}\text { Analysis of Comfort Conditions in Luxury } \\
\text { High-Rise Residences under the Effect of } \\
\text { Pandemic Period }\end{array}$} & \\
\hline $\begin{array}{l}\text { Corresponding } \\
\text { Author }\end{array}$ & \multicolumn{2}{|c|}{$\begin{array}{l}\text { Gözde GALİ TAŞÇI } \\
\text { Beykent University, Faculty of Engineering and Architecture, Interior Architecture } \\
\text { Department, gozdetasci@beykent.edu.tr }\end{array}$} & \\
\hline $\begin{array}{l}\text { Received Date } \\
\text { Accepted Date }\end{array}$ & \multicolumn{2}{|l|}{$\begin{array}{l}21.10 .2020 \\
15.12 .2020\end{array}$} & \\
\hline Author / Authors & Gözde GALİ TAŞÇI & ORCID: 0000-0002-4119-1080 & \\
\hline How to Cite & \multicolumn{2}{|c|}{$\begin{array}{l}\text { Gali Taşçı, G. (2020). Rezidanslarda Konfor Koşullarının Pandemi Dönemi Etkisinde } \\
\text { Analizi, Kent Akademisi, Volume, } 13 \text { (43), Issue 4. Pages, 701-721 }\end{array}$} & $\begin{array}{l}\text { Kent Akademisi } \\
\text { Urban Academy }\end{array}$ \\
\hline
\end{tabular}

\title{
Rezidanslarda Konfor Koşullarının Pandemi Dönemi Etkisinde Analizi
}

\section{ABSTRACT:}

The rapidly changing housing model after the Industrial Revolution has found a response with luxury high-rise residential buildings as a result of the changes people have gone through in line with their new lifestyles and needs, especially in cities that have transformed into an industrial city and we now call metropolis. This building typology is called 'Residence (Rezidans)' in residence. This typology also manifests itself in office buildings, and one of the main reasons for its intensive application is that more living or working units can be placed in smaller areas due to decreasing land areas and increasing land prices in the city center compared to the increasing population. Especially with the prominence of the industry and the establishment / placement of business life in the forefront of our lives, the need in the houses has been minimal, but the residences, which include the concept of 'luxury building', have been able to meet the needs of people, as such intensive working people continue to need to see themselves in a comfortable space. In this direction, this housing typology has become highly demanded. Until the COVID-19 virus epidemic, which created a significant change in our lifestyle, residence buildings and their reasons for use were mostly studied from socio-cultural perspectives. However, after the epidemic, we had more contact with these housing units than we have ever had before, in line with the fact that we spend a lot of time in the housing units, preferably more than our previous life. As a result, we started to notice some obvious deficiencies in this housing typology, which we were not aware of before and thought that we were fully responded to our needs, or that we could not realize even if it did not fully respond. These deficiencies have significant effects on the user comfort, psychology and

\footnotetext{
${ }^{1}$ Beykent University, Faculty of Engineering and Architecture, Interior Architecture Department, gozdetasci@ beykent.edu.tr
} 
hence can influence negatively the behavior of individuals. In this direction, in order to make a general analysis, it was tried to reach residents living in residence in Istanbul by preparing a questionnaire including comfort analysis for residence in residence buildings. The results of the questionnaire gave clear results from which some judgments could be reached, but these results were re-analyzed with 3 types of residence plans. In summary, especially due to the the changing perception in line with the pandemic, it has been revealed that residence buildings should be developed to meet the outdoor contact needs of individuals and changes should be made especially in the interior space plan organization.

KEYWORDS: High-Rise Residence, Housing Comfort, COVID-19, Pandemic, Psychology.

\section{ÖZ:}

Endüstri Devrimi sonrası hızla değişen barınma modeli, özellikle sanayi kenti olarak dönüşen ve artık metropol olarak andığımız kentlerde, insanların yeni yaşam tarzları ve ihtiyaçları doğrultusunda geçirdikleri değişimler sonucu, lüks yüksek katlı konut binaları ile bir karşılık bulmuştur. $\mathrm{Bu}$ bina tipolojisi, konutlarda 'Rezidans' olarak adlandırılmaktadır. Bu tipoloji, ofis binalarında da kendini göstermektedir ve yoğun uygulanmasının temel sebeplerinden biri de artan nüfusa oranla kent merkezinde azalan arsa alanları ve artan arsa fiyatları sebebi ile daha küçük alanlarda daha çok yaşam veya çalışma biriminin yerleştirilebilmesidir. Özellikle sanayinin ön plana çıkması ve iş yaşantısının hayatlarımızda ön sıraya yerleşmesi/yerleştirilmesi ile konut içlerinde ihtiyaç minimalimize olmuş, fakat bu denli yoğun çalışan insan, kendini konforlu bir alanda görme ihtiyacını sürdürdüğü için 'lüks bina' kavramını barındıran rezidanslar, insanların ihtiyacına cevap verebilmiştir. Bu doğrultuda, bu konut tipolojisi oldukça talep görmeye başlamıştır. Yaşayış tarzımız üzerinde önemli bir değişiklik yaratan COVID-19 virüs salgınına kadar rezidans binaları ve kullanım sebepleri çoğunlukla sosyo-kültürel açılardan incelenmekteydi. Fakat salgın sonrası konut birimlerinde zorunlu ve sonrasında da tercihen eski yaşantımıza kıyasla oldukça uzun zaman geçirmemiz doğrultusunda, yaşadığımız bu konut birimleri ile daha önce etmediğimiz kadar çok temas ettik. Bunun sonucu olarak da önceden farkında olmadığımız ve ihtiyacımıza tamamen cevap aldığımızı düşündügümüz veya tam olarak cevap vermese de fark edemediğimiz, bu konut tipolojisine ait belirgin bazı eksiklikleri fark etmeye başladık. Bu eksiklikler kullanıcı konforu üzerinde önemli etkilere sahip olarak, bireylerin psikolojilerini ve dolayısıyla davranışlarını olumsuz yönde etkileyebilmektedir. Bu doğrultuda, genel bir analiz yapılabilmesi amacıyla rezidans binalarında konut için konfor analizini içeren bir anket hazırlayarak İstanbul içinde rezidansta yaşayan sakinlere ulaşılmaya çalışıldı. Anket sonuçları bazı yargılara varılabilecek şekilde belirgin sonuçlar verdi fakat 3 adet tip rezidans planı ile bu sonuçlar tekrar analiz edildi. Özetle, özellikle pandemi sebebi ile değişen algı doğrultusunda kullanıcı konforunu sağlayabilmek amacıyla, rezidans binalarının bireylerin dış mekan temas ihtiyacını karşılamaya yönelik geliştirilmesi ve iç mekan plan organizasyonunda değişiklikler yapılması gerektiği ortaya çıkmıştır.

ANAHTAR KELIMELER: Rezidans, Konut Konforu, COVID-19, Pandemi, Psikoloji.

\section{“Rezidanslarda Konfor Koşullarının Pandemi Dönemi Etkisinde Analizi”"}

\section{GíRIŞ:}

İnsanlar için en önemli yaşam birimi konutlardır. Yaşama fonksiyonları, hayatla temas, çevresel ilişkilerin temeli konut birimlerinde gerçekleşir. Her birey için temel konfor alanı kendi yaşadığı konuttur.

Konut terimi günümüze gelirken çeşitli güncellemelere uğramıştır. En temel tanımıyla "bir ya da daha çok insanın ikamet ettiği yer, ev, mesken, ikametgah" olarak tanımlarız (Hasol, 2016). Eski yıllarda kalabalık aile yaşantısının daha yoğun olduğunu göz önünde bulundurarak konutlar da bu ihtiyaca yönelik daha geniş alanlara sahiplerdi. Fakat zaman içerisinde değişen hayat koşulları ve özellikle sanayinin aktif olduğu metropollerde, giderek konutta geçirilen zamanın kısıtlanması sebebi ile daha küçük alanlarda konut çözümleri oluşmaya başladı. Bununla beraber, metropol kent merkezlerinde arsaların da oldukça değer kazanması ile dikey büyüme hız kazandı ve sonucunda kuleleşme ve kulelerdeki birimlere yaşantıyı sığdırma günümüzün en pratik çözümü oldu. Bu çözüm, kimi kent sakini için oldukça uygun olurken, kimileri birimlere sığdırılan bu yoğun hayatı rahatsız edici buldu ve bu sebeple metropollerden daha küçük kentlere göç yaşandı. Tüm bunların sonucunda, sanayileşmenin ve ekonomik büyümenin devam etmesi amacıyla, büyük kentlerde kuleleşme çözümü kalıcı hale geldi. Türkiye'de Ankara, İstanbul, İzmir, Konya ve Mersin'de bu çözüme yönelik binalar mevcuttur (The Skyscraper Center, 2020). Amacı konut birimleri oluşturmak 
olup içerisinde farklı fonksiyonlarda mekanlar da bulunduran bu kompleks, lüks yüksek katlı bina tipi ülkemizde 'rezidans' olarak adlandırılmaktadır.

Türkiye'deki mevcut bina stokuna yönelik olarak yapılan araştırmalar doğrultusunda, Türkiye İstatistik Kurumu'ndan (TÜIK) alınan veriler ile konut binası tipolojileri içerisinde rezidans binalarının yapım sıklığının yükselme eğiliminde olduğu belirlenmiştir (Yılmaz, 2015). Popülerleşmelerinin bir başka sebebi, genellikle bu bina tipolojisinde yaşamayı tercih eden orta-üst ve üst gelir kesiminin değişen ve artan konut binası ihtiyaçlarıdır (Taşçı, 2017). Daha önceleri konut içerisindeki ihtiyacın temelini 'barınma' oluştururken zaman içerisinde bunun 'konforlu barınma' ihtiyacına dönüşmesi gibi, günümüzde de konut içi ve bina içi konfora yönelik ek ihtiyaçlar gelişmiştir. Bu ihtiyaçlar bazen çok kritik olmayıp sadece talep kısmında kalsalar da bu talepleri karşılamaya yönelik olarak rezidans bina tipolojisi geliştirilmiş ve bu ek istekleri karşılayabildiği düşünüldüğü için tercih edilen bir konut binası tipolojisi haline gelmiştir. Bu konuda Bilgin, N., endüstri toplumlarında konut çevrelerinde yapılan değişikliklerdeki amacın, kullanıcıların istek ve ihtiyaçlarını karşılamaktan çok, üretimde verimi arttırmak ve konut ile konut donatımının tüketimini hızlandırmak olduğunu belirtmiştir. Temel konfor ihtiyaçları, mekansal fonksiyonlara göre değişiklik göstermekle beraber, 1sıl ve görsel konfor kriterleri olarak standartlarca belirlenmiştir (Atmaca, 2016).

Bu makale kapsamında, günümüzde taleplerin arttığı bu bina tipolojisinin kullanıcı konforu açısından incelenmesine yer verilmiştir. Göregenli, M., insanların yaşamak ya da terk etmek konusunda kendi tercihlerini çoğunlukla kullanmadıkları, içinde geçirilen zamanların giderek azaldığı evler; neredeyse bir nostaljiyle anılmaya başlanan ev yaşamı; giderek artan kentçi hareketliliğine bağlı olarak evlerin tarihini oluşturan insanların sayısının sürekli olarak artması ile aidiyet duygusunun öneminin giderek yitirilip yitirilmediğine dikkat çekmektedir. Özellikle içinden geçtiğimiz pandemi günlerinde evlerimizde daha önce hiç olmadığı kadar uzun vakit geçirdik. Belki de 'ev' kavramı ilk kez tam anlamını içerecek şekilde kullanıldı. Yaşadığımız ve belki heyecanla seçtiğimiz bu mekanları, ilk kez bu kadar yoğun deneyimleme firsatı bulduk. Bu sayede de daha önceden farkına varmadığımız bazı artı ve eksilerin farkına vardık. Aslında yaşanılan konutlardaki mevcut mekansal konfor koşulları değişmemiş olmasına rağmen, konut mekanında geçirilen sürenin artması, iç mekan ile temasın daha yoğun olması ve beraberinde konutun tüm alanlarının daha uzun süreli kullanımı, pandemi sürecinin konut kullanıcılarının iç mekan konfor koşullarını daha detaylı bir şekilde değerlendirmelerine sebep olmuştur. Bu durum, mevcut konfor koşullarının pandemi sürecinde analiz edilmesi ihtiyacını doğurmuştur. Bu doğrultuda, rezidans olarak adlandırdığımız lüks yüksek konut binalarında mimari planlamaya bağlı kullanıcı konforu analizinin, pandemi dönemindeki yoğun kullanımın etkisi altında yapılması gerekliliği tespit edilmiştir. Bu amaçla, makale kapsamında, rezidans binalarının tipolojik nitelikleri ve yapım tekniklerinden de kaynaklı bazı kısıtlamalar sebebi ile özellikle günışı̆̆ı ve taze hava ihtiyacının karşılanması konusunda yeterli verimin elde edilip edilemediği ve iç mekan organizasyonunun yaşanılabilirlik açısından değerlendirmeleri yapılmıştır. Bu değerlendirmeler çeşitli proje incelemeleri ve bu çalışma için hazırlanmış bir anket çalışması sonucu baz alınarak gerçekleştirilmiştir.

\section{Literatür Araştırması}

Rezidans binaları Türkiye'de olduğu gibi global olarak da yapımı yükselişte olan bir konut tipolojisidir. Tüm ülkelerde benzer sebeplerle, özellikle sanayi merkezini oluşturan kentlerde bu konut tipolojisi sıklıkla uygulanmaktadır. Bu kapsamda da rezidans olarak adlandırdığımız bu lüks yüksek konut binalarına yönelik çeşitli araştırmalar mevcuttur.

Araştırmaların birçoğunu, binanın mimari özellikleri ve yüksek bina olmasından ileri gelen kısıtlamaları sebebi ile havalandırma konusu oluşturmaktadır. Hariri, N., artan nüfus yoğunluğu sebebi ile rezidans binalarına talebin arttı̆̆ında hem fikir olmuş, fakat bu binaların özellikle sıcak ve nemli iklimlerde havalandırma ihtiyacının nasıl çözüleceğine dair bir yöntem geliştirilmesi gerektiğini ve bunun belki dikey şaftlar gibi yeni mimari önerilerle sağlanabileceğini öne sürmüştür. Bu gibi çalışmalar rezidans binalarının mimari yapıları üzerinde oldukça etkilidir. Nitekim Omrani, S., vd., mevcut doğal havalandırma stratejilerinin yüksek binalar için uygun olmadığını, bu sebeple farklı yöntem araştırmaları yapılması gerektiğini ileri sürmüş ve çeşitli alternatifler üretmişlerdir. Aydın, D. ve Mıhlayanlar, E., yüksek konut yapılarında iç ortam kalitesinin incelenmesi amacıyla yaptıkları araştırmada bu yapılarda 1sıl konfor, doğal havalandırma ve ses yalıtımının en iyi çift cidarlı cephe kullanımı ile çözülebileceğini tespit etmişlerdir. Bu araştırmalarında yapı stokundaki yüksek binaların \%45 oranında ofis, $\% 50$ oranında ise konut binası olduğunu ve bu sebeple konutlarda konfor koşullarının sağlanması amacı ile cephe üzerinde çalışmalar 
yapılabileceğini öne sürmüşlerdir. Yine bu bina tipolojisinde, özellikle cephelerdeki geniş yüzey alanı ve bunun binaların enerji performansını artırmaya yönelik değerlendirilmesi son dönemde sıklıkla ele alınmaktadır. Buna yönelik olarak Taşçı, G., çalışmasında rezidans binalarında çift cidarlı cephe uygulaması ve arka cephe yüzeyinde 1sı yutuculuğu yüksek film kaplaması kullanımının iç mekan ısıl konforu üzerindeki etkilerini incelemiş ve rezidans binalarında ileri cephe teknolojisi yaklaşımlarının oldukça verimli sonuçlar verdiğini, böylelikle isıtma giderlerinin düşürülebileceğini tespit etmiştir.

Bununla beraber bu binalara ihtiyacın neden doğduğunu araştıran sosyo-kültürel incelemeler barındıran çalışmalar da mevcuttur. Sadıkoğlu, H. ve Özsoy, A., Türkiye'de 90’lı yıllar itibari ile özellikle üst gelir grubunun dışa kapalı ve kendi içerisinde korunaklı bu konut tipolojisini tercih ettiklerini ortaya koymuş ve geçmişten bugüne, sosyal tabakalaşma sonucu konut tercihlerinin özellikle üst gelir grubunda nasıl değiştiğini incelemişlerdir. Bu araştırma kapsamında dönemin mimari üsluplarının da etkisi incelenmiştir. Sönmez, A., L., yapım teknikleri ve mimari tasarım bazında tipolojik özellikleri bulunduğunu ve belirli bir kesime hitap ettiğini açıkladığı rezidans binalarının, kentsel mekanın sosyo-kültürel sürdürülebilirliği üzerindeki etkisinin yadsınamayacak düzeyde olduğunu belirtmiştir. Güzelci, H., konut reklamlarına yönelik yaptığı araştırmasında, rezidans binalarının topluma sunuluş şekli üzerinde durmuş ve binalarda formsal bazda değişiklikler olsa bile iç mekan ve nitelik bazında rezidans binalarının tamamının çok benzer olduğunu belirtmiştir. Bu binaların, temel olarak tüketime yönelik hedefler çerçevesinde şekillendiklerini ortaya koymuştur.

Rezidanslara yönelik araştırmalar incelendiğinde, bu bina tipolojisine ihtiyaç duyulduğu ve talep olduğu, ancak mevcut tasarım tiplerinin henüz beklentiyi tam karşılamadığı, fakat geliştirilmeye açık olduğu ortaya çıkmaktadır. Bu bina tipolojisinin kent yapısı üzerindeki etkileri ise değişime açık olmayıp, kalıcı bazı deformasyonlara sebep olmaktadir.

\section{Yöntem}

Türkiye'de sayılabilecek ilk yüksek bina, 1974 yılında Ankara'da yapımı tamamlanan Türkiye Petrolleri Anonim Ortaklığı (TPAO) Genel Müdürlük Binası'dır. Yüksekliği yaklaşık 100 metredir. Bu binadan itibaren $1974-2020$ yılları arasında Türkiye'de 100 metre ve üzerindeki yüksek binaların \%45'ini konut binaları, \%28'ini ofis binaları, \%19'unu karma kullanımdaki binalar, \%6'sını oteller ve \%1'ini hükümet binaları oluşturmaktadır (The Skyscraper Center, 2020). Yüksek binalar sanayi ve teknolojiye paralel bir şekilde artış eğilimindedirler. Tarihsel bazda bakıldığında ilk yüksek binaları, ofis binaları oluştururken günümüze doğru ilerledikçe konut binalarının artış gösterdiği görülmektedir. Bu da önemli bir sosyo-kültürel göstergedir. Yine aynı dönem içerisinde yapılan binalar incelendiğinde, strüktürel malzeme olarak \%93'ünün beton, \%6'sının kompozit, \%1'inin ise çelik kullanılarak inşa edildiğini görmekteyiz (The Skyscraper Center, 2020).

Rezidans binaları, çok katlı olmaları dolayısıyla yapım tekniklerinden ileri gelen bazı kısıtlamaları barındırmaktadır. Çoğunlukla betonarme konstrüksiyon kullanılan bu bina tipolojisi, yüksek bina grubuna da girmesi sebebi ile rüzgar yükleri ve emniyet kaynaklı olarak, özellikle belirli bir yükseklikten sonrası için, pencere açılımı ve balkon kısıtı bulundurmaktadır. Bu durumun etkileri, literatür araştırmaları kapsamında çoğunlukla bina havalandırmasına yönelik olarak incelenmiştir. Ancak 2020 yılında yaşamış olduğumuz, COVID-19 isimli virüs salgını sebebi ile evlerde yaşanılan karantina sürecinde, insanlar temel ihtiyaçlarının karşılanıp karşılanamadığını daha net ayırt edebilmişlerdir. $\mathrm{Bu}$ ihtiyaçlar önceleri çoğunlukla aydınlatma ve havalandırma iken, bu süreçte manzara - diş görüş de buna eklenmiştir. Bununla birlikte temel amacı da konutları daha kompakt hale getirmek olan bu bina tipolojisinin iç mekan organizasyonunun kullanıcılar için uygunluğu da araştırılması gereken bir soru olmuştur.

$\mathrm{Bu}$ amaçla 'Yüksek Konut Binalarında Kullanıcı Konforu' üzerine bir anket hazırlanmıştır. 2020 yılına kadarki rezidans bina stokunun \%71'i İstanbul'da yer almaktadır. Bu nedenle inceleme stok yoğunluğunun olduğu İstanbul ili için yapılmıştır. Anket yalnızca İstanbul'da rezidans binalarında oturan kişilere açılmıştır. Sorular dört bölümde oluşturulmuştur:

- Konuta Ait Genel Bilgiler

- Günışı̆̆ından Faydalanma ve Çevresel Faktörler 


\section{- Dış Mekan ile Bağlantı Olanakları}

\section{- $\quad$ İç Mekan Konfor Analizi}

$\mathrm{Bu}$ kapsamda İstanbul'da farklı rezidans binalarında yaşayan 100 kişiye ulaşılmıştır. Ancak anket sonuçları incelendiğinde bazı katılımcıların kavram karmaşası sebebi ile anketi doldurdukları fakat rezidans olarak tanımladığımız binalarda yaşamadıkları tespit edilmiştir. Bu katılımcıların anket verileri elenerek, kalan 71 adet anket verisi değerlendirilmiştir. Elde edilen sonuçlar grafikler oluşturularak yüzdelik olarak incelenmiştir. Anket, 14.05.2020 tarihinden 14.08.2020 tarihine kadar katılımcılar tarafından cevaplanmıştır.

Anket sonuçlarının değerlendirilmesinin ardından hem anket çalışmasına katkı sağlamak hem de elde edilen bulguların doğruluğunu yeniden analiz etmek amacıyla, İstanbul'da yer alan farklı rezidans projelerinin kat planlarının incelenmesi ile 3 adet tip rezidans kat planı oluşturulmuş ve bu kat planları ile de analizler yapılarak sonuç bulgular elde edilmiştir.

\section{Değerlendirme}

$\mathrm{Bu}$ bölümde öncelikle anket sonuçları grafikler oluşturularak değerlendirilmiş ve bazı çıkarımlar elde edilmiştir. Bu çıkarımları takiben İstanbul'da bulunan farklı rezidans projelerinin kat planlarının incelenmesi sonucu 3 adet rezidans tip kat planı oluşturulmuş ve anket sonuçlarının çıkarımları ile birlikte değerlendirilmiştir.

\subsection{Anket Sonuçlarının İncelenmesi}

Anket 4 bölümde yapılmıştır ve her bölüm kendi içerisinde analiz edilmiştir. Bu nedenle makale kapsamında da rezidanslarda bulunan konutlara ait genel bilgi, günışığından faydalanma ve çevresel faktörler, dış görüş ve iç mekana bağlı konfor analizleri ayrı ayrı ele alınmıştır.

\subsubsection{Konuta Ait Genel Bilgiler}

Rezidans binalarına ve bu binalarda yer alan konutlara ait genel bilgiler incelenirken, öncelikle katılımcıların hangi rezidans kompleksinde yer aldıkları öğrenilmiştir. Bu sorunun önemli sebeplerinden bir tanesi, günümüzde modern malzemeler ile inşa edilen, standart apartman formundan farklı formlarda inşa edilen, iç mekan yerleşim planında da günümüzün karakteristik özelliklerini yansıtan kompakt tasarımın uygulandığı tüm binalara "rezidans" olarak isim verilmektedir. Oysaki rezidans binaları kat sayısı bakımından oldukça spesifik bir niteliğe sahiptirler ve yüksek bina olmaları aynı zamanda içinde bulunduğumuz zamanın gerekliliklerini yansıtan bir semboldür. Bu doğrultuda, verilen yanıtlar incelendiğinde 29 adet anketin projelerin isminde rezidans geçtiği veya kullanıcılara fonksiyon olarak çağrışım yaptığı için doldurulduğu, fakat bu binaların tanım çerçevesinde rezidans binası olmadıkları tespit edilmiştir. Bu sebeple, bu anketler değerlendirmeden çıkarılmıştır. Bu kısımdan elde edilen cevaplar doğrultusunda ankette yer alan rezidans çeşitliliği de belirlenmiştir. Bu sorunun yanıtına göre 39 farklı rezidans binasına ait anket doldurulmuştur.

Rezidans binaları site içerisinde yer alabildikleri gibi, kent içerisinde tekil binalar olarak da konumlanmaktadırlar. Tekil binalar, site içerisinde yer alan binalara göre bulundukları çevreden daha kopuk ve o dokuda gerilim oluşturur nitelik taşımaktadırlar. Buna yönelik bir inceleme yapabilmek amacıyla sorulan soruya cevaben katılımcıların \%83'ü yaşadıkları rezidans binasının bir site içerisinde yer aldığını belirtmiştir. Bu yanıtlara istinaden sitelerin veya tekil rezidansların ortak alan durumunu inceleyebilmek amacıyla sorulan soruya katılımcıların yalnız \%59.1'i sitelerindeki ortak sosyal tesis ve/veya rekreasyon alanının yeterli olduğunu belirtmiştir. Bu durum, özellikle kapalı sitelerde veya dışarıdan kopuk yüksek binalarda yaşayan insanlar için oldukça önemlidir. Yalnızca pandemi dolayısıyla oluşan karantina süreci ve sonrasında değil, temel olarak bir çevre düzenlemesi problemine işaret etmektedir. Anket sonuçlarına göre çoğunluğu sitede yer alan bu konutlarda yaşayan sakinler, çoğunlukla site içerisinde sosyal aktivitede bulunmak ve sosyalleşmek tercihinde olacaktır. Ancak yetersiz bir çevresel düzenleme bu ihtiyacın karşılanamamasına, dolayısıyla sosyal anlamda bir konforsuzluk etkisi oluşmasına neden olacaktır. Bu tür bir etki, uzun bir süreç sonucunda etkisini konut kullanımı haricinde sitenin yetersiz bulunması ve dolayısıyla siteden uzaklaşma, başka bir yeri tercih etme şeklinde gösterebilecektir. Bunun yanında bireysel bağlamda da zaman içerisinde mutsuzluk hissine sebep verebilecektir. Aynı soruya katılımcıların \% 4.2'si ortak bir alanın hiç 
bulunmadığını belirtmiştir. Bu durum da rezidans binalarının özellikle bir site içerisinde bulunmadığında kentten ve çevresinden de kopuk, yalnızca yüksek bir barınma birimi olarak var olduğu projelere dikkat çekmektedir.

Katılımcıların konutlarındaki yaşam sürelerini tespit etmek ve buna göre konutlarının hizmetine dair farkındalıklarının ne seviyede olduğunu belirleyebilmek amacıyla sorulan COVID-19 salgını öncesinde ve sonrasında hafta içi evlerinde günde ortalama kaç saat geçirdiklerine ait yanıtlara göre, salgın öncesinde katılımcıların \%38'i 10-15 saat, \%30.9'u 510 saat geçirdiklerini belirtirken; salgın sonrasında katılımcıların \%60.6'sı günde 20-24 saatlerini evlerinde geçirdiklerini belirtmişlerdir. Bu saat farkı oldukça önemli olmakla birlikte, pandemi dönemi etkisi ile konutların temel yaşam birimleri haline geldiklerinin ispatı olmuştur. Katılımcılara salgın kaynaklı karantina dönemi ve sonrasında dişarıda yürüyüş yapma ve dolaşma miktarına dair sorulan soruya \%50.7'si nadiren, \%21.1'i günde 1-2 saat, \%21.1'i hiç çıkmadım, \%7'si gün aşırı 1-2 saat olarak cevap vermiştir. Yine konut içerisinde geçirilen vakti ölçmeyi destekleyici sorulardan bu süreçte iş yerine gidilip gidilmediğine dair olan soruya katılımcıların \%39.4'ü evden çalıştığ $1, \% 30.9$ 'u çalışmadığ $1, \% 19.7$ 'si iş yerine gittikleri, \%9.8'i iş yerine kısa süreli olarak gittikleri şeklinde yanıt vermiştir. Bu kısma ait yanıtlarla da rezidans sakinlerinin, bu dönemde, günlerinin çoğunu evlerinde geçirdiklerini ortaya koyabilmekteyiz.

İleriki bölümlerde konut içi organizasyonun dağılımının nasıl bir çerçeve içerisinde olduğunu anlamak için konutların yaklaşık net alanları sorulmuştur; katılımcıların \%29.6's1 101-150 m², \%29.6's1 151-200 m², \%23.9'u 51-100 m², \%9.8'i 201-250 m², \%5.6'sı $250 \mathrm{~m}^{2}$ üzeri, \%2.8'i $50 \mathrm{~m}^{2}$ veya altı olarak cevap vermiştir. Bu alanlarda kaç kişinin yaşadığının belirlenebilmesi amacı ile sorulan soruya katılımcıların \%29.6'sı 1, \%29.6'sı 2, \%22.5'i 3, \%18.3'ü 4 veya üzeri olarak yanıt vermiştir.

Bu bölüm kapsamında elde edilen sonuçlar doğrultusunda, salgın sebebi ile rezidans sakinlerinin çoğunlukla evlerinde vakit geçirme sürelerinin uzadığı tespit edilmiştir. Bu süre içerisinde çoğunluğu site içerisinde yer alan rezidans binalarında yaşayanlar, genel olarak site içerisindeki alanlarda dışarıdalık hissiyatını yaşayabilmiş ve ev harici farklı bir alanda olabilmişlerdir. Bu anlamda sitelerin ortak alanlarındaki nitelik yetersizliğinin düzenlenmesi, aynı zamanda site içerisinde yer almayan rezidans binalarında oluşan ortak alan ihtiyacının karşılanmasının gerekliliği ortaya çıkmaktadır.

\subsubsection{Günışığından Faydalanma ve Çevresel Faktörler}

Konutların günışığından faydalanabilme ölçütünü, dolayısıyla doğal aydınlatma katkısı ile yapay aydınlatmanın daha az kullanılabilmesi ve doğal aydınlatmanın insan psikolojisi üzerindeki pozitif etkilerin sağlanabilmesi ölçütlerini tespit etmek amaçlı sorular sorulmuştur.

Şekil 3.1'de yer alan grafikte katılımcıların "Konutunuzda günışığından faydalanabilme ölçütünüzü nasıl değerlendirirsiniz?" sorusuna vermiş oldukları yanıtların dağılımı görülmektedir. Yetersiz yanıtını hiçbir katılımcı seçmemiştir, bu nedenle grafikte yer almamaktadır. Katılımcılar konutlarında günışı̆̆ından faydalanma ölçütlerini $\% 57.7$ oranında çok iyi olarak değerlendirmişlerdir.
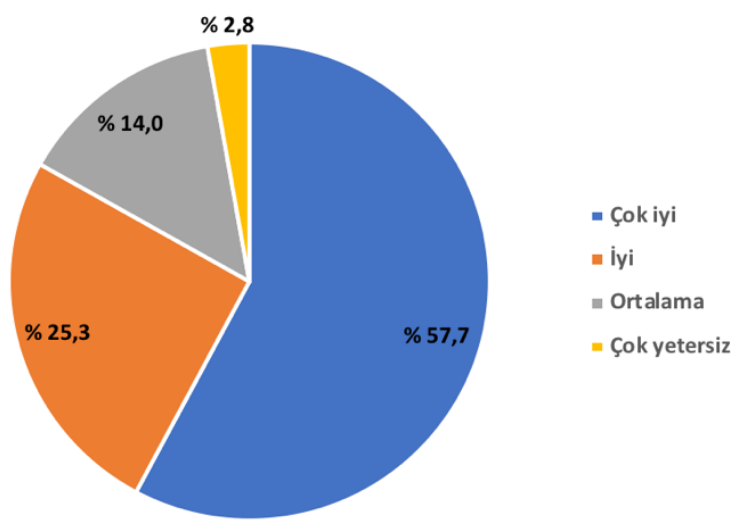

Analysis of Comfort Conditions in Luxury High-Rise Residences under the Effect of Pandemic 


\section{Şekil 3.1. Konutlarda Günışı̆̆ından Faydalanma Memnuniyeti}

Yaşanılan konutta dış ortam ile sağlanan iletişimde genel manzaranın ne olduğuna ait soruya verilen yanıtların grafiği Şekilde 3.2.'de yer almaktadır. Birden fazla seçenek seçilebilen bu soruda \%59.2 oranında şehir manzarası iken bunu \%39.4 ile komşu bina izlemektedir. Komşu binanın manzara olması hem bir rezidans sakini için tanımlanan konfor kapsamı ile çelişmekte hem de taze hava ve günışığından faydalanma miktarını azaltmaktadır. Bu bağlamda katılımcıların ilk soru olan günışığından faydalanma memnuniyetine verdikleri yanıt objektif olarak yeniden değerlendirilmelidir. Komşu bina manzarası site içerisinde yer alan rezidans binalarında karşılaşılan bir durumdur. Site alanı içerisinde binalar arası mesafe yeterli miktarda ise manzara anlamında komşu bina büyük bir problem olmayabilmekte ancak rezidanslar yüksek binalar oldukları için her koşul altında yaşanılan daireye komşu bina gölgesi düşmektedir. $\mathrm{Bu}$ da günışığından faydalanabilme ölçütünü azaltmaktadır. Bu problemi minimuma indirebilmek amacıyla avan proje aşamasında binaları yalnızca kabuk olarak oluşturarak gölge analizlerini yapmak yeterli olacaktır.

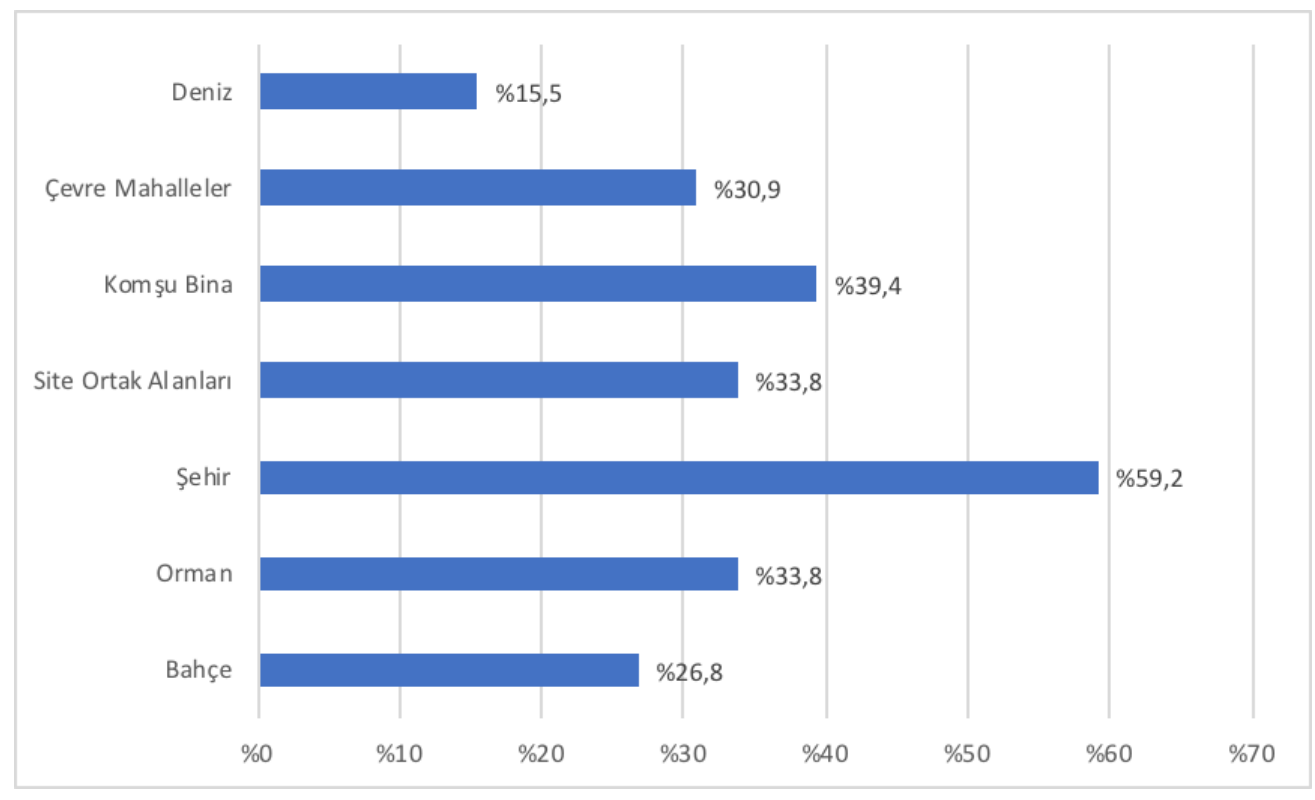

Şekil 3.2. Konut Manzaraları

Odaklanılan konuyla ilgili olarak katılımcılara salgın sebebi ile uzun süre evlerimizde bulunduğumuz süreçte günışığına duydukları ihtiyacı nasıl karşıladıkları sorulmuştur. Bu soruya verdikleri yanıtlar, Şekil 3.3.'te grafik olarak özetlenmiştir. Yanıtlar çerçevesinde \%49.3 balkonda oturarak günışı̆̆ı ihtiyacını karşıladığını belirtmiş, bu oranı takiben \%45.1 pencere kenarında oturarak günışı̆̆ı ihtiyacını karşıladığını belirtmiştir. Rezidans binalarında genel kat planı tipolojileri incelendiğinde balkon mevcudiyetinin oran olarak azınlıkta olduğu belirlenmiştir (Y1lmaz, 2015). Ancak araştırmaları takiben, bazı güncel projelerde balkon yapısı da yer almaya başlamıştır. Ankette rezidans projesi dağılımı herhangi bir kısıta tabi değildir, bu nedenle yoğunluklu olarak balkonu olan rezidans projelerinden katılım olması sebebi ile oran \%49.3'lere çıkmış olabilecektir. Araştırmalar sonucunda rezidans binalarında genel balkon yapısını Fransız balkon tipi oluşturmaktadır. Bu tip, balkon amaçlı kullanıma hizmet etmemekte, ancak pencereden farklı olarak dış mekan ile arada bir cam kapı yer almakta ve bu da döşemeye kadar bir açıklık oluşması ile kullanıcısının dış mekan ile daha çok temas ettiği hissiyatını oluşturmaktadır. Bu araştırmaları destekler nitelikte \%45.1 ile ikinci en yüksek cevabı oluşturan "pencere kenarında oturum" rezidans binalarında kullanıcıların günışığından faydalanmak amacıyla taze hava alıp dış mekan ile temas kurabilecekleri standart bir balkon/teras/kat bahçesi yapısının eksikliğini ortaya koymaktadır. 


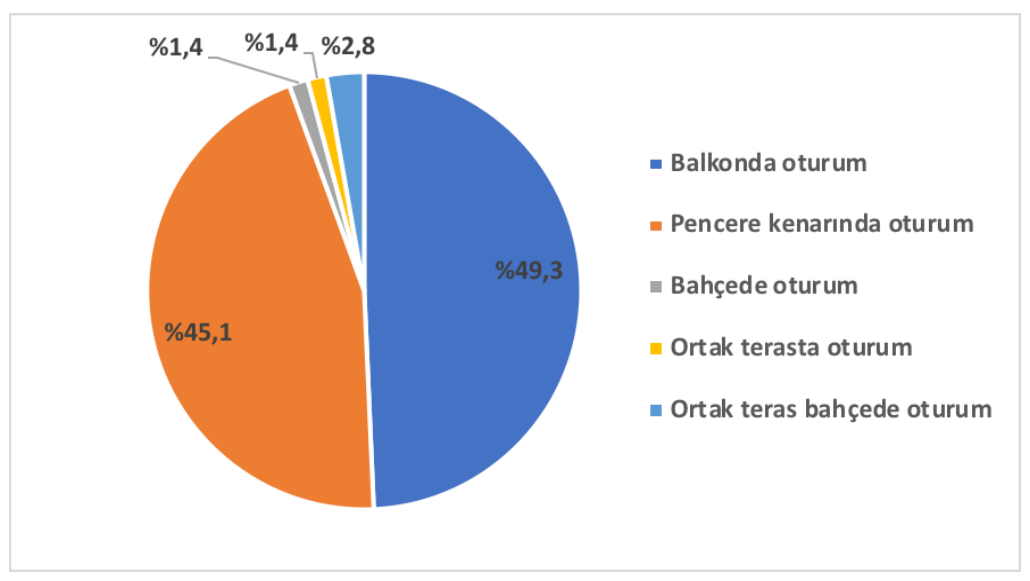

Şekil 3.3. Konutlarda Günışı̆̆ından Faydalanma Modeli

Günışığından faydalanmanın ve çevresel faktörlerin incelendiği bu bölümde, pencerelerin açılış biçimi ve dolayısıyla taze hava alım miktarı da analiz edilmiştir. Katılımcıların \%63.4'ü pencerelerinin klasik düzende açıldığını, \%35.2'si pencerelerinin vasistas açıldığını, \%1.4'ü pencerelerinin açılmadığını belirtmiştir.

Bu bölümün son sorusu olan ve birden fazla seçenek hakkı veren "Konutunuzda cepheden iç mekanlara derinliği ve dolayısıyla günışı̆̆ı faydalanma miktarını nasıl tanımlarsınız?" sorusuna katılımcıların \%54.9'u "Mutfak, salon ve yatak odaları gibi temel alanlar günışığından yeterli faydalanıyor", \%36.6'sı "Derinlik az, her mekan günışığından oldukça iyi faydalanıyor", \%12.7'si "Çok derin, günışı̆̆ından yeterince faydalanılamıyor", \%7'si "Komşu bina/binalardan gölge düşüyor, yeterince günışığı alınamıyor" ve \%2.8'i "Saydam yüzey az, o nedenle günışığından iç kısımlarda yeterince faydalanılamıyor" yanıtını vermiştir. Yanıtlar incelendiğinde, birden fazla seçenek seçilebilmesi sebebi ile bazı katılımcıların hem "Çok derin, günışığından yeterince faydalanılamıyor" hem de "Mutfak, salon ve yatak odaları gibi temel alanlar günışığından yeterli faydalanıyor" seçeneklerini seçtiği görülmüştür. Bu da bazı rezidans binalarında temel alanların günışığından yeterli miktarda faydalandığı, ancak sirkülasyon alanları gibi diğer alanların yeterince faydalanamadığı görüşünü oluşturmuştur.

\subsubsection{Dış Mekan ile Bağlantı Olanakları}

Bu bölümde pandemi ile birlikte oldukça sık konuşulmaya başlanan ve güncel olarak tüm konut tipolojilerinde kullanımı yeniden gündeme alınan konut dahilinde dış alan kullanımı üzerinde yoğunlaşılmıştır. Çalışma kapsamında, balkon; bir binada üstünde başka katlar da bulunan ve katlarda dışarıya doğru çıkma olarak yapılmış, çevresi korkuluk ile çevrilmiş yapı (Hasol, 2016), teras; binada en üst katlarda bulunan üstü açık çıkma veya düz çatı yapısı olarak tanımlanmıştır. Teras, ara katlarda da yer alabilir, bu durumda üstü açık olan çıkmalar çalışma kapsamında teras olarak kabul edilmiştir. Her ikisi de oturmaya elverişli alanları bulunan mekanlar olmalıdır. Bu tanımlar katılımcılara da verilmiş ve anketi tanımlara uygun olacak şekilde doldurmaları talep edilmiştir.

Yaşanılan konutta dış mekan ile bağlantı amaçlı hangi yapısal alanın bulunduğunun analiz edildiği ilk soruya verilen yanıtların değerlendirilmesi ile oluşturulan grafik Şekil 3.4'te yer almaktadır. Katılımcıların \%52.1'i balkonu bulunduğunu, \%23.9'u Fransız balkonu bulunduğunu, \%1.4'ü bahçesi bulunduğunu, \%22.5'i ise balkon, Fransız balkon, teras ve bahçeden hiçbirinin bulunmadığını belirtmiştir. Seçilebilecek yanıtlar içerisinde bulunan teras seçeneği katılımcılar tarafından seçilmemiştir. Bu yanıtların doğruluğu için katılımcı olunan projeler incelenmiş ve katılınan dairelerde teras yapısının bulunmadığ doğrulanmıştır. Bahçe yanıtı da analiz edilmiştir ve bu yanıtı veren katılımcıların, rezidans giriş katında oturduğu ve dairelerin özel bahçe kullanımlı olduğu belirlenmiştir. Sonuçlardan hareketle, rezidans binalarında yoğunluklu olarak balkon mevcudiyetinden söz edilebilir, ancak 3.1.2 Günışığ Faktörü bölümünde kullanıcıların \%45.1'inin günışığından pencere kenarında oturum ile faydalandığını burada tekrar hatırlayarak mevcut balkonların konfor durumlarının araştırılması gereği ortaya çıkmaktadır. Bu doğrultuda, başka bir çalışmada rezidans binalarında mevcut bulunan balkonların alan ve rüzgar bazında incelemelerinin yapılması bu sonuçları aydınlatabilecektir, bu araştırma kapsamında bu ihtiyaçlar belirlenerek ortaya konulmaktadır. Mevcut araştırmalar ışığında temel nitelik olarak yüksek katlı olan rezidans binalarında 10 kata kadar rüzgar hızının benzer 
ölçüde olduğu, 15. katta bu hızın arttığı, 20. katta ise 15. kata göre daha yüksek olduğu ve maksimum rüzgar hızlarının kenarlarda gerçekleştiği tespit edilmiştir (Dikmen, 2011). Bu doğrultuda 'kenar' olarak söz edilen cephede yer alan balkon yapıları, 10. kattan sonra giderek artan bir rüzgar hızına maruz kalmaktadır. Bu sebeple, rezidanslarda yer alacak balkonları 10. kat sonrasında kapanıp açılabilen bir düzende ya da rüzgar yönünde bariyerli bir şekilde tasarlamak gerekmektedir. Mevcut projelerde bu şekilde bir uygulama bulunmuyorsa balkonların rutin bir kullanımda olması mümkün olamayacaktır.

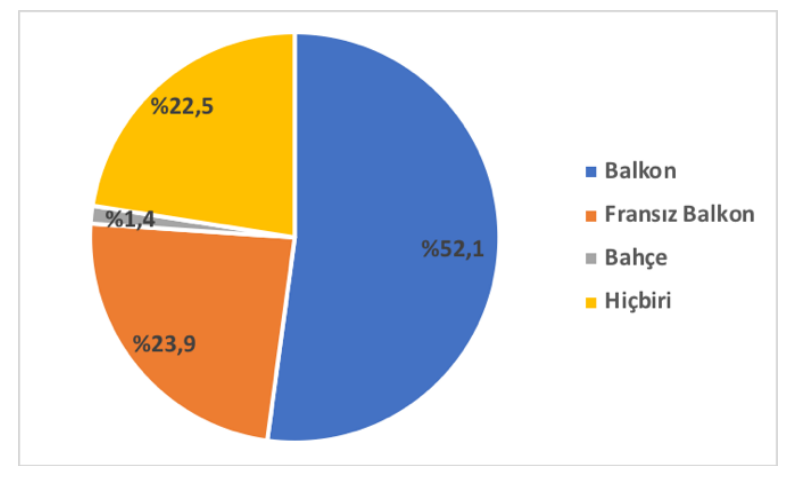

\section{Şekil 3.4. Rezidans Konutlarında Yer Alan Dış Mekan Bağlantı Alanları}

Sorulara balkon yapısı irdelenerek devam edilmiştir. Katılımcıların açık balkon veya tamamen açılabilir kapalı balkon alanı ortalamalarına yönelik soruya cevapları Şekil 3.5'te yer almaktadır. Sadece balkonu bulunan katılımcıların yanıt verdiği bu sorunun cevaplarından oluşan grafik değerlendirildiğinde, katılımcıların $\% 11.3$ 'ü ortalama $1-5 \mathrm{~m}^{2}$ arası balkon alanının bulunduğunu, yine \%11.3'ü $16-20 \mathrm{~m}^{2}$ arası balkon alanının bulunduğunu ve yine aynı oranda \%11.3'ü $25 \mathrm{~m}^{2}$ üzeri balkon alanının bulunduğunu belirtmiştir. Bu durumda balkon alanının çok çeşitlilik gösterdiğini ve katılımcıların yoğunlukla yer aldığı rezidans projesine göre bu yanıtların ağırlığının değişebileceğini belirtmek gerekmektedir. Bu balkonların, söz konusu "ev"e kapanma halinde "içeride dışarıda olmayı yaşama" hissiyatının karşılı̆̆ını verebilecek yapıya sahip olup olmadıkları, alan ortalamasına göre değişkenlik gösterecektir. Ancak tümünü, hava ile teması ve manzara ihtiyacını karşılayabilecek çıkmalar olarak niteleyebiliriz.

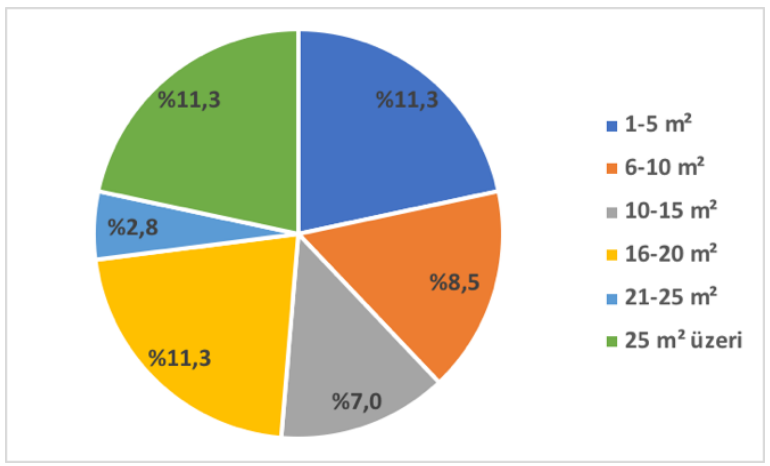

Şekil 3.5. Açık veya Tamamen Açılabilir Kapalı Balkon (Cam Balkon) Alanları

Pandemi, karantina ve kişisel karantina uygulamaları ile balkon kullanımı arasındaki bağlantıyı incelemek için sorulan pandemi öncesi ve sonrasında iklim koşulları elverdikçe günde ortalama balkon kullanım saati sorularına katılımcıların verdikleri yanıtlar Şekil 3.6'da yer alan grafiklerde gösterilmiştir. 


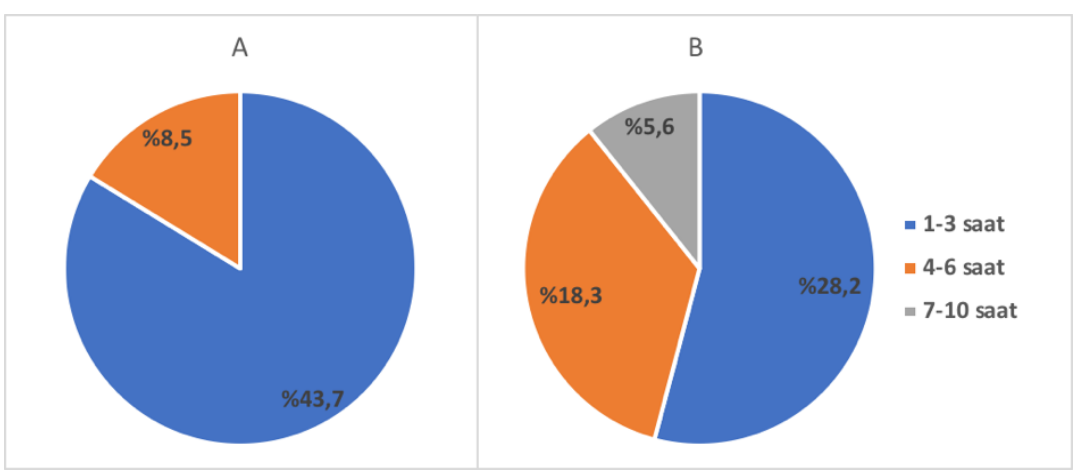

Şekil 3.6. A) Katılımcıların Pandemi Öncesi Balkonda Günde Ortalama Kaç Saat Geçirdikleri B) Katılımcıların Pandemi Sonrası Balkonda Günde Ortalama Kaç Saat Geçirdikleri

$\mathrm{Bu}$ grafiklere göre, pandemi sonrası katılımcıların balkonda geçirdikleri süre artmıştır. Daha önce iklim koşulları elverdikçe katılımcıların \%43.7'si günde 1-3 saat arasını balkonlarında geçiriyorken, pandemi sonrası bu oran \%28.2'ye düşmüştür. Günde ortalama 4-6 saat geçirenlerin sayısı artarken, pandemi sonrasında 7-10 saat geçirenler de olmuştur.

\subsection{4. İç Mekan Konfor Analizi}

Pandemi ve getirisi olan konutlarda yaşam süresinin uzaması, sadece açık mekanlara duyulan talebi arttırmadı, aynı zamanda konut iç mekan düzenlemeleri de daha fazla dikkat edilen ve konut içi yaşantıdaki konforu doğrudan etkileyen önemli bir kriter oldu. Bu bölümde katılımcılara temel olarak rezidans binalarının iç mekan yerleşim organizasyonu değerlendirilmek üzere sorular sorulmuştur.

İlk olarak katılımcılara önceki bölümün de devamı niteliğinde olacak şekilde, COVID-19 salgını sebebi ile evlerinde vakit geçirdikleri süreçte bahçe ve/veya açık oturum eksikliği hissedip hissetmedikleri sorulmuştur. Katılımcılardan $\% 53.5$ 'i evlerinde açık oturum eksikliği hissettiğini belirtirken, \%46.5'i bu eksikliği hissetmediğini belirtmiştir. Bu soruya verilen cevap önceki bölümde balkon/bahçe kullanımı ile ilgili verilen cevaplar ile birlikte değerlendirildiğinde, katılımcı olan rezidans sakinlerinin günışığından faydalanmak amaçlı balkon/bahçe kullanımı imkanı bulabilmiş olsalar da bu alanların dış mekan teması için yetersiz kaldığına işaret etmektedir. Bu noktada çeşitli senaryolar düşünülebilmekle beraber net olarak üç madde ele alınabilir; birincisi, mevcut balkon alanlarının yetersiz olabileceğidir ve bu durumda balkon alanlarını projelerde, metrekareyi azalttığı düşünüldüğü için yan yapı unsuru olarak tasarlamak yerine, temel yapı elemanları ile birlikte düşünülen bir bileşen haline getirebilecek çalışmalar yapılması gerekliliği ortaya çıkmaktadır. İkincisi, önceki bölümde de cevaplar doğrultusunda belirtildiği gibi rezidans binalarının, yüksek binalar olması sebebi ile balkonlarda iklimsel koşullardan kaynaklı olarak konforun sağlanamaması ve bu durumda fiziki olarak balkon var olsa da konut sakinlerinin balkonu kullan/a/mıyor olabileceğidir. Bu durumda da avan proje aşamasındayken çevresel analizlerin eksiksiz yapılması, hakim rüzgar yönünün belirlenmesi ve yine önceki bölümde belirtildiği gibi gerekli durumlarda balkonları kapanıp açılabilen yapıda veya hakim rüzgar yönünde siper olabilecek bir yapı elemanı ile birlikte uygulamak çözüm olabilir. Üçüncüsü, balkonların sadece birer çıkma olarak ele alınmaması, kat bahçesi kavramının kat bazında veya daire bazında rezidans binalarında ele alınabileceği yönünde bir tasarım önerisidir.

Katılımcılara "COVID-19 salgını sonrasında, konut tasarımlarında hangi yapı için keşke olsaydı dediniz" diye sorulmuş ve birden çok seçenek seçebilecekleri belirtilmiştir. Yanıtların analizi sonucu oluşturulan grafik Şekil 3.7'de yer almaktadır. Yanitlar çerçevesinde bahçe talebi \%53.5, balkon talebi \%32.4, teras talebi \%26.8, açılabilir pencere talebi \%7, daha çok pencere (saydam yüzey) talebi ise \%4.2 oranında olmuştur. Bu sonuçlar da bir önceki sorunun cevapları ile oluşan çıkarımları destekler niteliktedir; konutlarda bahçe/bitki/yeşil talebi oluşmuş durumdadır. Bu da yalnızca standart balkon uygulaması ile çözülemeyecek bir taleptir. Ancak uygun yapım teknikleri ile her kat yüksekliğinde balkonları daire sakinleri tarafından bahçe gibi de kullanılabilecek formda uygulamak mümkündür. 


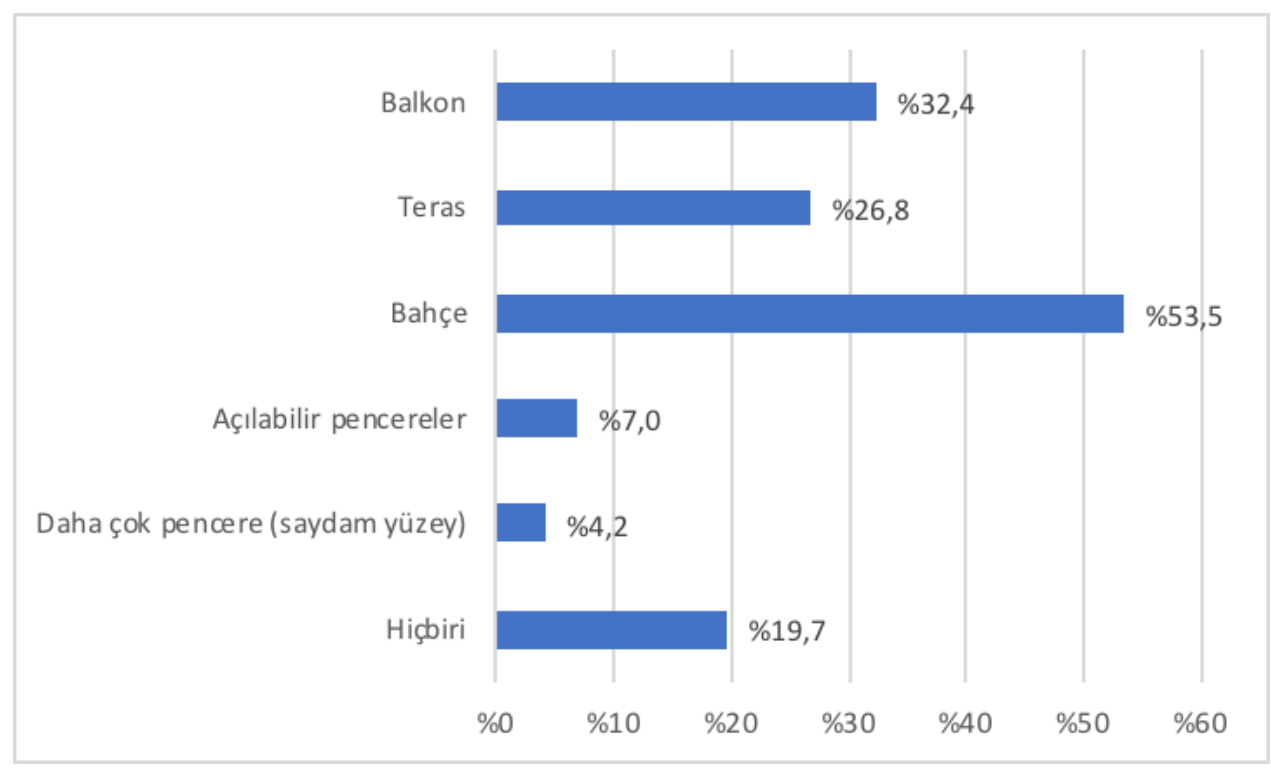

Şekil 3.7. Rezidans Sakinlerinin COVID-19 Salgını Sonrasında Konutlarında Olmasını Talep Ettiği Yapılar

Mekansal analizleri konutun iç kısmına yönlendirerek "Konutunuzdaki iç mekan yerleşim planı ile ilgili aşağıdakilerden hangisi veya hangileri doğrudur" diye sorulan ve birden çok seçenek seçilebilen soruya verilen yanıtlar Şekil 3.8'de yer alan grafik üzerinde gösterilmiştir. Bu durumda rezidanslarda konut içi yerleşim planında çoğunlukla mutfak ve salonun birleşik bir hacimde yer aldığı ve salonların daire girişine açık olmak kaydıyla ayrı bir oda olmak yerine açık bir mekan oldukları belirlenmiştir.

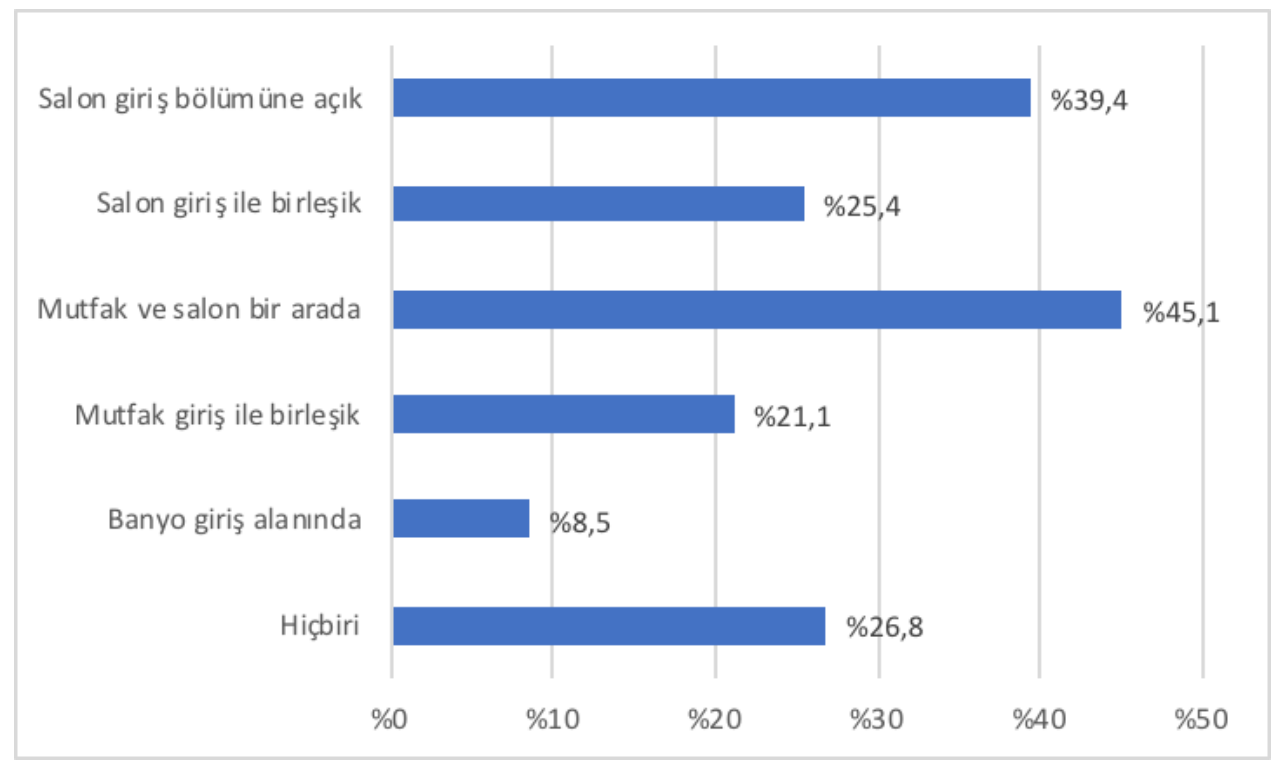

Şekil 3.8. Rezidanslarda Konut İç Mekan Planlaması

Yukarıdaki soruyu tamamlamak amacıyla katılımcılara şıklar verilerek hangisinin yaşadıkları konut için doğru olduğu sorulmuştur. Şekil 3.9'da bu sorunun yanıtlarının oluşturduğu grafik yer almaktadır. Bu soruda katılımcılara kendi isteklerini de yazabilecekleri belirtilmiş ancak katılımcılar genel olarak sorudaki şıklar üzerinden yanıt vermiştir. Yalnızca 1 kişi "ebeveyn banyosu olsaydı daha iyi olurdu", 1 kişi "balkon olsaydı daha iyi olurdu" şeklinde ekleme yapmiştır. 


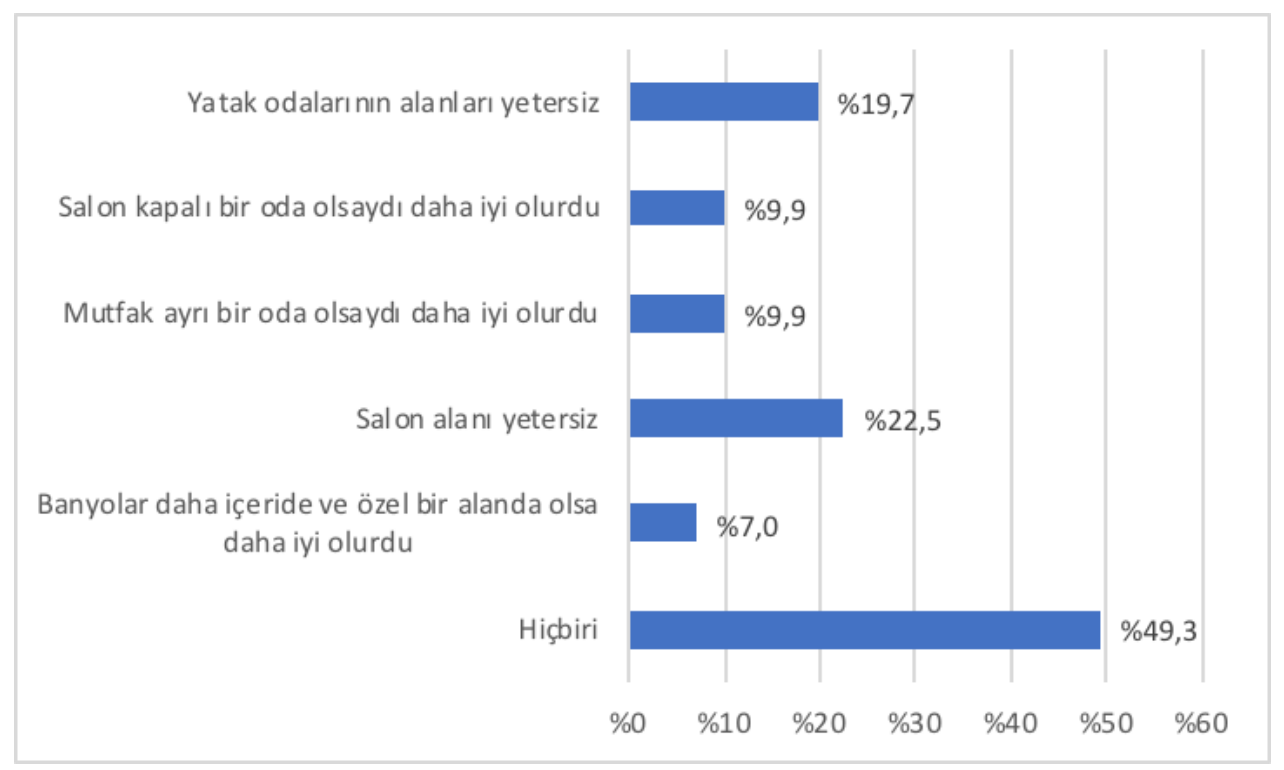

Şekil 3.9. Rezidanslarda Konut İçi Yerleşim Planı Eksikleri

Şekil 3.8 ve Şekil 3.9'daki yanıtlar değerlendirildiğinde, katılımcı rezidans sakinlerinin yarısının mahal alanlarından memnun olmadığı, yatak odaları, salon, mutfak alanlarının yetersiz bulunduğu, bazı katılımcıların Şekil 3.8'de de görülen mutfak-salon birlikte kullanımdan memnun olmadığı, banyoların mekansal yerleşiminin bazı rezidans sakinleri için konforsuz olduğu sonuçları ortaya çıkmaktadır. Yanıtların incelenmesi doğrultusunda; mutfak alanının yetersiz bulunması çoğunlukla salon ile bir arada kullanımda karşılaşılan bir memnuniyetsizlik olarak tespit edilmişsir. Salon alanının yetersiz bulunması ise hem salonun kapısı kapatılabilen ayrı bir mahal olmamasından kaynaklanmakta, hem de alan ölçüsü olarak yetersiz bulunmasından kaynaklanmaktadır.

Tüm veri analizleri sonucunda, iç mekan konfor analizini detaylı bir şekilde toparlayabilmek açısından katılımcılara üç adet konfor değerlendirme sorusu sorulmuştur. İlki "Konut içi mekansal yerleşim planı günün çoğunu evde geçirdiğinizde konforunuz açısından ne kadar uygun hissettirdi?" sorusudur. Katılımcıların yanıtlarından oluşturulan grafik Şekil 3.10 'da gösterilmiştir. Elde edilen yanıtlar çerçevesinde, katılımcıların çoğu \%43.7 ile yaşadıkları konutun iç mekan organizasyonunu konforlu bulmakta, bunu takiben \%31'i ortalama konforda bulmaktadır. "Çok konforlu" seçeneğinin tercihi yoğunluk olarak üçüncü sırada olmuştur.

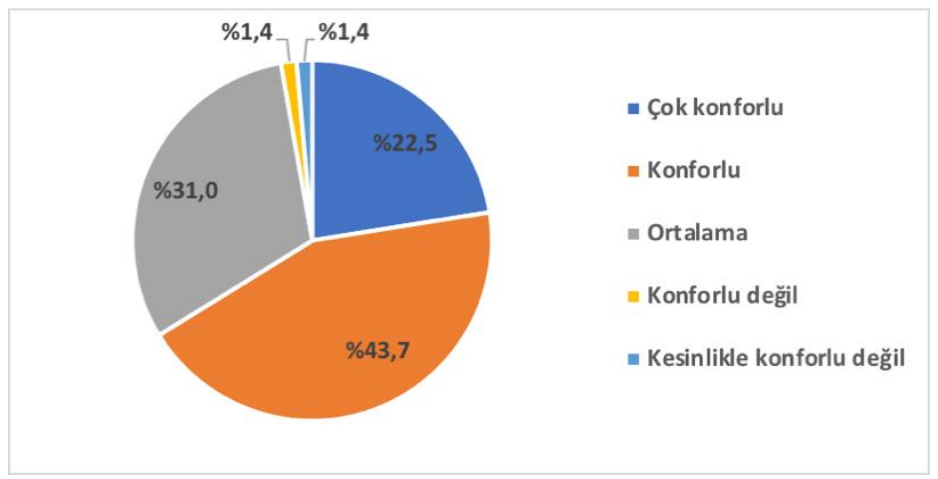

Şekil 3.10. İç Mekan Organizasyonu Kaynaklı Konfor Analizi

Bu yanıtlar Şekil 3.9.'daki yanıtlar ile birlikte değerlendirildiğinde, katılımcıların yarısı kadarının yaşadıkları konutun iç mekan yerleşim planı ile ilgili eleştirileri olduğu tespit edilmiştir, Şekil 3.10’u oluşturan yanıtlarda da tüm katılımcıların çok konforlu dememiş olmasının sebeplerinin bir kısmını bu eleştiriler oluşturmaktadır. Ancak başka 
sebepler de olup olmadığını anlamak amacıyla farklı bir soru ile konut içi mekansal yerleşim yeterince konforlu değilse sebeplerinin ne olduğu sorulmuş ve birden fazla seçenek hakkı verilmiştir. Yanıtlardan oluşturulan grafik Şekil 3.11'de yer almaktadır. Yanıtlara göre bu şıklar çerçevesinde, Şekil 3.10'da olduğu gibi katılımcıların yaklaşık yarısının konfor problemi bulunmamaktadır. Problem yaşayan katılımcılar ise sebep olarak \%23.9 ile en yoğun olarak balkon veya teras olmamasını, bunu takiben \%18.3 ile iç mekanda bireysellik için yeterli özel alan olmamasını, \%14.1 ile taze hava alım anlamında havalandırma problemi yaşadıklarını belirtmişlerdir. Balkon ve teras eksikliği konusu, önceki bölümde yoğun şekilde incelenmiştir. İkinci en yüksek konforsuzluk sebebi olan iç mekanda bireysellik için yeterli özel alan olmamasına ise rezidans iç mekan yerleşiminde, kompakt bir tasarım metodu izlenerek mekanların birbirine daha açık ve birleşik olması, alışılan konut içi sirkülasyon alanlarının da daha kompakt olması neden olmaktadır. Bu sonuç da yine Şekil 3.8 ve Şekil 3.9'daki analizlerle desteklenmektedir. Bu problem ancak iç mekan organizasyonunda daha net ayrımların yapıldığı ve özel alanların oluşturulduğu bir yerleşim planı ile çözülebilir. Diğer en yüksek konforsuzluk sebebi olan taze hava alım anlamında havalandırma problemi ise, pencerelerin vasistas açılması sebebi ile oluşmaktadır. Ancak önceki bölümde katılımcıların \%63.4'ü pencerelerinin klasik düzende açıldığını belirtmiştir. Bu durumda yüksek katlarda rüzgar yükü etkisi sebebi ile pencerelerin çoğunlukla taze hava almak için kullanılamadığını söylemek mümkündür. Fakat burada tekrar üzerinde durulması gerekir ki rezidans binalarında yüksek katlarda, bir balkona açılmadığı takdirde pencereler ancak vasistas düzende açılabilmektedir. Bu anlamda katılımcıların bu soruya vermiş oldukları yanıtın doğruluğu değerlendirmeye açıktır. Şekil 3.11'de yer alan yanıtlara ek olarak, 1 kişi konutunun manzarasının oldukça rahatsız edici olduğunu, 1 kişi dişarıdan yoğun gürültü geldiğini, 1 kişi ise yönetimsel problemler olduğunu belirtmiştir.

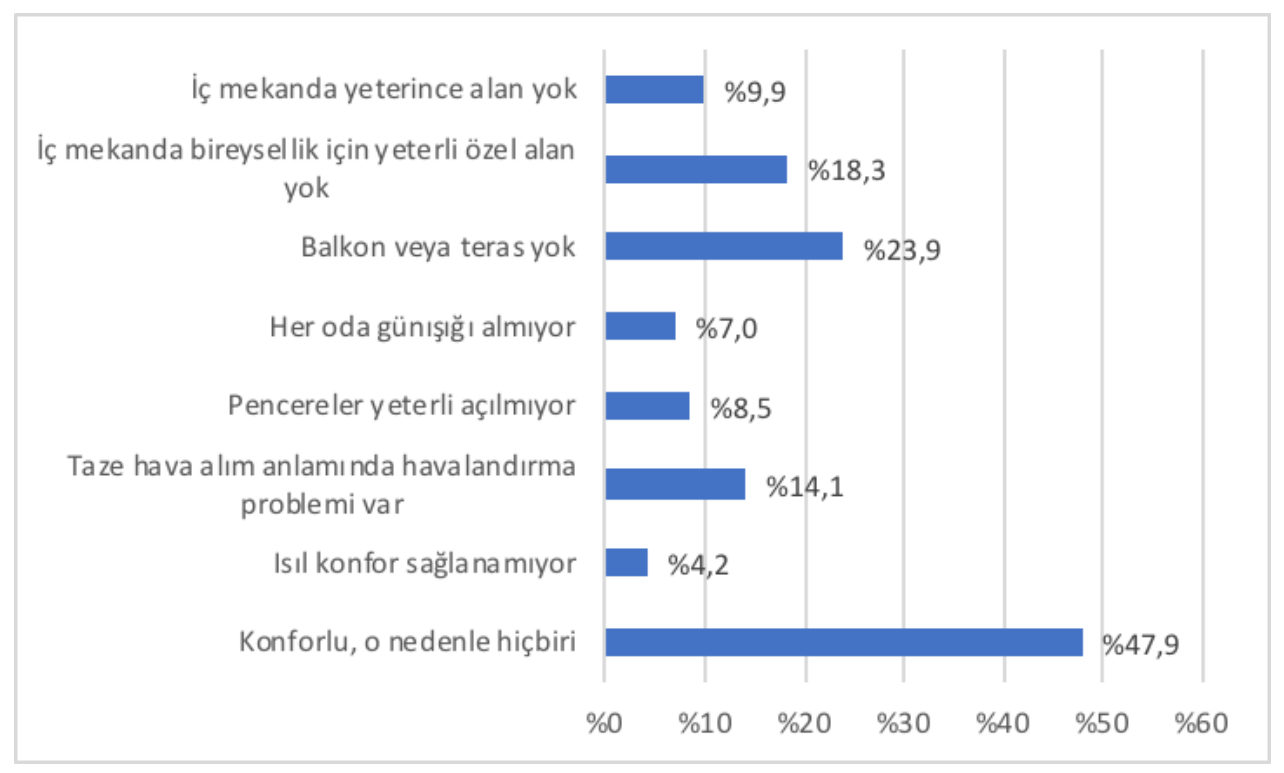

Şekil 3.11. İç Mekandan Kaynaklı Konforsuzluk Sebepleri

Anketin son sorusu olarak, tüm anket içerisinde sorulan ve özellikle son konfor bölümü doğrultusunda katılımcılara düşündürülen konfor koşulları doğrultusunda, genel olarak konutlarının konfor durumunu nasıl değerlendirdikleri sorulmuştur. Yanıtlar Şekil 3.12'de yer alan grafik ile belirtilmiştir. Katılımcıların çoğunluğu \%49.3 ile iyi, bunu takiben \%29.6's1 ortalama olarak yanıt vermiştir. Bu yanıtların oransal dağılımı, iç mekan organizasyonunun konfor açısından değerlendirildiği ve Şekil 3.10'da grafiği bulunan yanıtlarla yaklaşık olarak aynıdır. Bu durumda, "çok iyi” seçeneğinin tercih edilmemesini kullanıcıların konforu üzerinde iç mekan organizasyonunun oldukça önemli bir etkiye sahip olması ile yorumlayabilmekteyiz. Balkon, bahçe, vb. daha sonraki aşama olarak tamamlayıcı etkenlerdir. Katılımcılar yine "çok iyi”" yanıtını düşük bir oranda tercih etmiş ve çoğunluk bazı konforsuzluklar bulunduğunu belirtmiştir. 


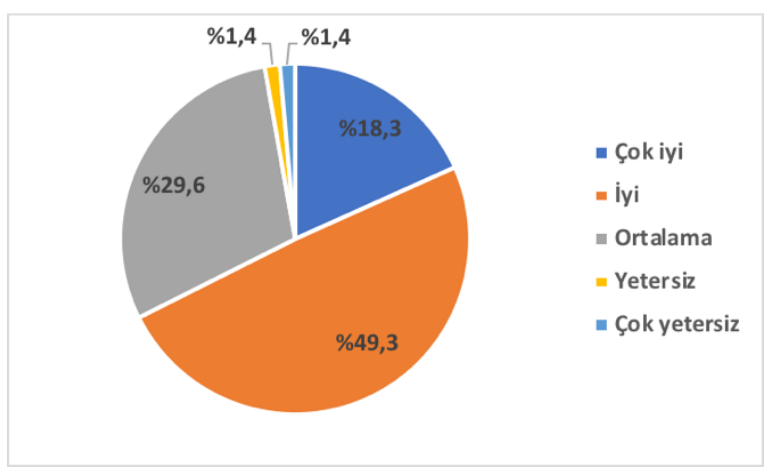

Şekil 3.12. Konuta Dair Genel Konfor Analizi

\subsection{Rezidans Binalarında Kompakt Kat Planları}

Bu bölümde, rezidans binalarında kullanımı yaygın olan kompakt daire kat planlarına ait 3 adet plan analiz edilmiştir. $\mathrm{Bu}$ incelemeye, anket sonuçlarından özellikle iç mekan organizasyonuna yönelik konfor problemleri çerçevesinde elde edilen sonuçlar nedeniyle ihtiyaç duyulmuştur. Anket sonuç verilerinin, kat planları ile görselleştirilmesi ve katılımcıların cevaplarının netliğinin değerlendirilmesi, mevcut yapılarda katılımcı yanıtlarından daha farklı bir durumun olup olmadığının incelenmesi amaçlanmıştır. Katılımcıların yaşadıkları rezidans binaları ile İstanbul'da yer alan farklı rezidans binalarının kat planları üzerinden, günışı̆ı̆ından faydalanma olanakları, dış mekan ile temas alanları ve iç mekan organizasyonu yeniden incelenmiştir. Bu kısımda temel olarak iç mekan organizasyonu üzerinde durulmuştur.

Rezidans binalarında bulunan iç mekan organizasyonları her projede, projenin konsepti çerçevesinde yenilikler kazanmaktadır. Ancak anket sonuçlarında da görüldüğü üzere, bazı mahallerin özel alan olmaması veya iç mekanda yeterli alan bulunmaması problemleri, rezidans kat planlarında genel iç mekan organizasyon çerçevesini oluşturmaktadır. Bu doğrultuda yapılmış detaylı bir araştırma kapsamında, Türkiye'deki rezidans projelerinde ağırlıklı olarak mutfak-salon-giriş alanlarının bir arada olduğu tespit edilmiştir (Yılmaz, 2015). Yapplan araştırma çerçevesinde, İstanbul'da yer alan farklı rezidans binalarının kat planları incelenmiş ve sonucunda tip kat planları oluşturulmuştur. Araştırma sonuçlarına göre iç mekan yerleşim planları çoğunlukla benzerdir ve tipik olarak mutfaksalon bir arada, salon açık, tüm mahaller birbirine temas halinde olup, cephe daha değişken bir yapıdadır. Bu araştırmadan günümüze gelinen sürede yapılan projelerde bu durum farklılaşmamış, ancak binalarda (özellikle mutfak için) özel alan tercihi de olabileceği gözetilerek alternatif kat planları da yer almaya başlamıştır. Bu doğrultuda rezidans binalarında, iç mekanda bütünsel olarak bir kompaktlıktan bahsederken, mekansal olarak projeye ve seçime göre özel mahallerin de bulunduğundan söz edebiliriz. Kompakt tasarım modeli, bazı kullanıcılar için tercih sebebi iken, genel olarak daha kalabalık dairelerde (2 kişi ve üzeri) maliyet parametresi haricinde tercih edilmemektedir. Bir başka tercih sebebi ise projenin konum, yüklenici firma, yaşayanlar gibi sebeplerle tercih edilmesi, ancak proje içerisinde yalnızca bu tür kompakt planların yer alması, yani başka seçenek olmamasıdır. Makale kapsamında herhangi bir projeyi hedef olarak göstermemek amacıyla, incelemeler doğrultusunda, rezidans kat planlarında çoğunluğu oluşturan mekansal organizasyon tipleri çerçevesinde yazar tarafindan tip kat planları oluşturulmuştur. Rezidanslarda en sık görülen iç mekan yerleşim özelliklerini yansıtan bu planlar, bir adet $1+1$ ve iki adet $2+1$ kat planından oluşmaktadır.

Şekil 3.13'te 1+1 kat planı örneği yer almaktadır. Oluşturulan dairenin net kullanım alanı $67.7 \mathrm{~m} 2$ 'dir. Bu kat planına ait iç mekan organizasyonu diğer tüm rezidans daire kat planlarına anahtar model teşkil etmektedir. Sözü edilen tüm kompakt tasarım parametreleri bu anahtar kat planında yer almaktadır. Plan incelenirse, salon ve mutfak mahallerinin bir arada, birbirlerine açık olarak kullanıldığı görülmektedir. Buna ek olarak mutfak ve salon hacmi aynı zamanda girişe ve yatak odasına giden hole de açıktır. Bu durumda, tüm daire içerisinde yatak odasında kapalı hacimde bulunmak haricinde özel bir alan bulunmamaktadır. Ancak bu dairenin 1+1 olduğu göz önünde bulundurularak iç mekanda özel alanın aranmayabileceği düşünülebilir. 


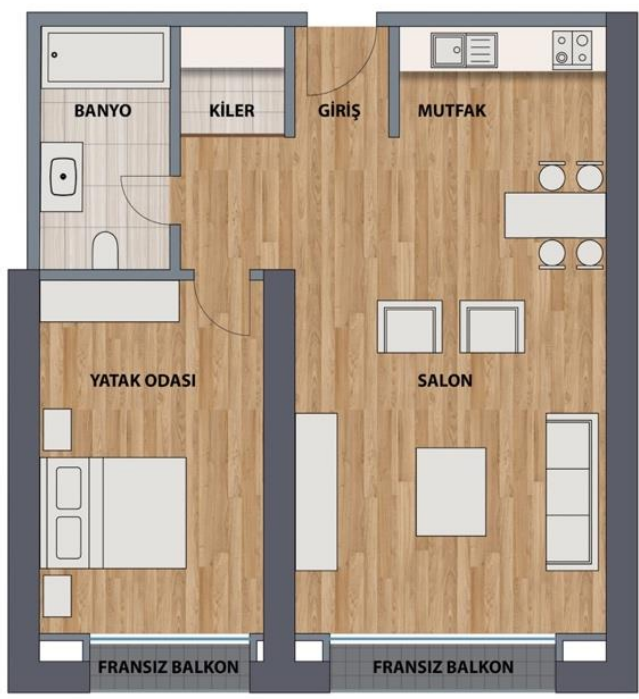

\section{Şekil 3.13. Rezidanslarda 1+1 Tip Kat Planı}

Şekil 3.14'te 2+1 kat planı örneği yer almaktadır. Oluşturulan dairenin net kullanım alanı 92.6 m2'dir. Bu kat planı, Şekil 3.13'te yer alan 1+1 kat planının benzeri ve araştırma sonuçlarına göre rezidans binalarında yoğun olarak kullanılan 2+1 kat planı modelidir. Bu kat planında da benzer şekilde, mutfak ve salon mahallerinin bir arada kullanımı görülmektedir, bu iki mahal birbirine açıktır. Bununla beraber mutfak ve salon hacmi girişe ve yatak odalarına giden hole de açıktır. İki farklı odanın yer aldı̆̆ böyle bir dairede, mahremiyet arzusu 1+1 dairedekinden farklı olacaktır. Bu sebeple, bu yerleşim planı çerçevesinde yalnızca yatak odalarının kullanımı ile karşılanabilecek bu mahremiyet talebi yeterli karşıllı̆ını bulamayabilir. Aynı zamanda giriş, mutfak ve salon hacimleri ile yatak odası alanının yakın bir temas içerisinde olması da kapı varlığına rağmen arzu edilen özel alan ihtiyacını sağlayamayacaktır. $\mathrm{Bu}$ tip bir yerleşimde, öncelikli olarak yatak odalarına gidişin ayrılması gerekmektedir. Bunu takiben, bireysel aktivite için ihtiyaç duyulacak ek alanların projeye dahil edilmesi gerekecektir.

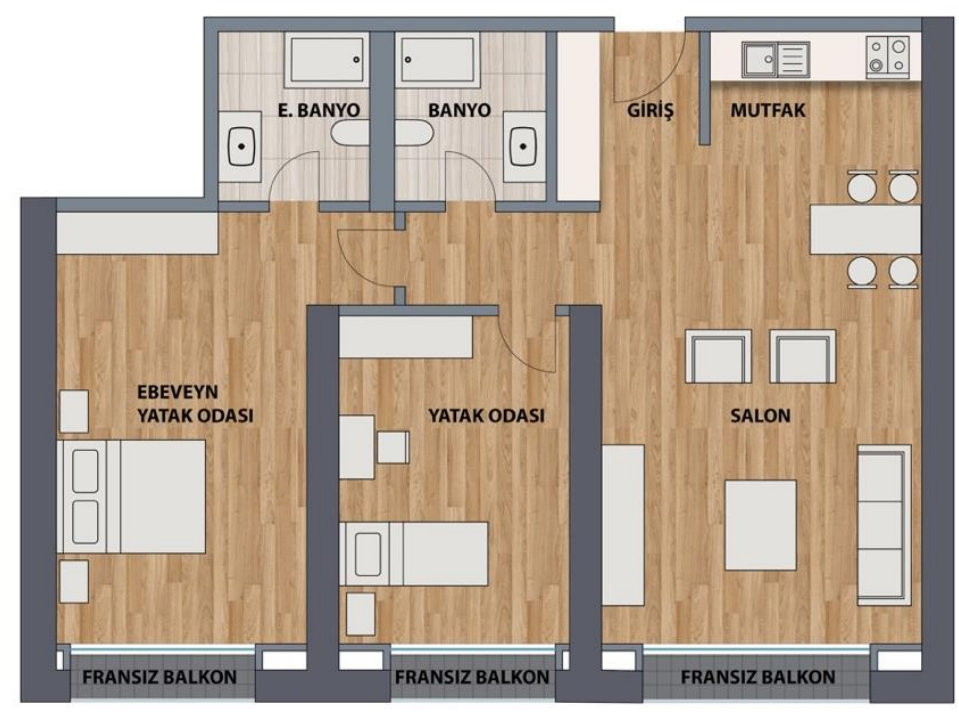

Şekil 3.14. Rezidanslarda 2+1 Tip Kat Planı 
Şekil 3.15'te mahallerin birbirinden ayrı olduğu alternatif bir $2+1$ kat planı yer almaktadır. Oluşturulan dairenin net kullanım alanı $86.8 \mathrm{~m} 2$ 'dir. Bu kat planında ön plana çıkan organizasyonel unsur mutfak ve salon mahallerinin ayrılmasıdır. Ancak geri kalan kompakt iç mekan organizasyonu bu modelde de korunmaktadır; tüm mahaller birbirlerine bakmakta ve giriş holüne açılmaktadır. Bu anlamda da mahremiyeti sağlayabilecek tek yapı elemanı kapı olmakta ve sadece kapı ile arzu edilen mahremiyet seviyesi karşılanamamaktadır. Yatak odalarına ulaşımın direk giriş alanı ile temas içerisinde olması, zaten bireyselliğin yaşanabileceği başka bir özel alan bulunmayan bu yerleşim planı çerçevesinde, mahremiyet ihtiyacının karşılanamamasına ve kişilerin problem yaşamalarına sebep olacaktır. Dolayısıyla anket sonuçlarında da Şekil 3.11 'de yer alan ve katılımcıların \%18.3'ünün "iç mekanda bireysellik için yeterli özel alan yok" ve \%9.9'unun "iç mekanda yeterince alan yok" cevapları açıkça bu plan tiplerinden kaynaklanmaktadır. Ek olarak, salon ve yatak odası alanlarında, lüks konut idealinden uzak olarak alanların dar olması, bireysel aktiviteler için yetersiz kalmaktadır.

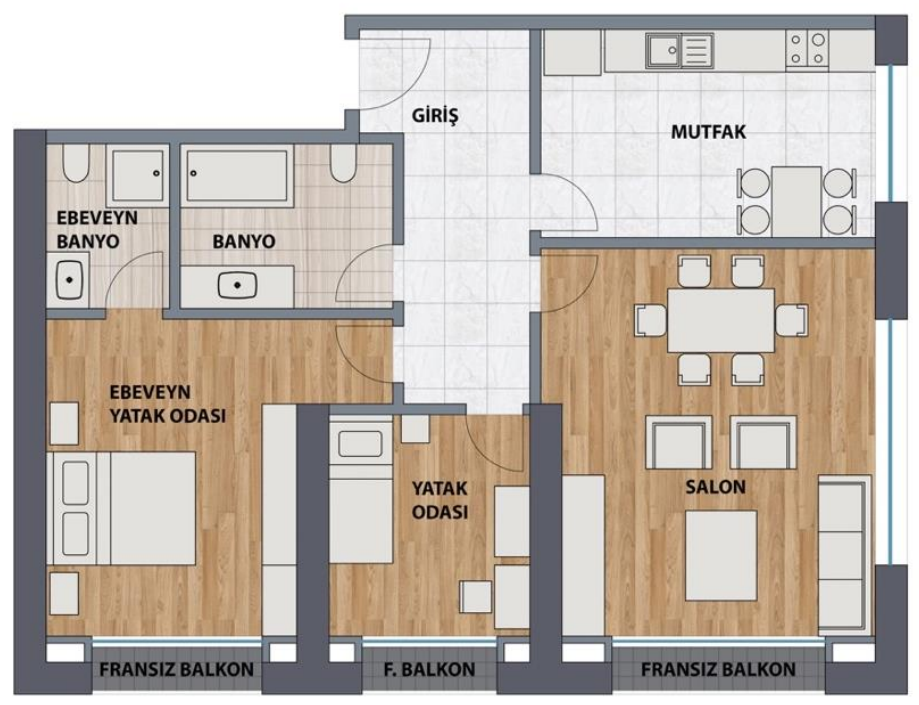

Şekil 3.15. Rezidanslarda Alternatif 2+1 Kat Planı

Bu plan tipinde, bir sirkülasyon alanı ve oradan ortak alanlar ile özel alanlara ayrı dağılım sağlanması düşünülmelidir. Bununla beraber, tüm odalar sadece yatak odası olarak düşünülmüş olup, $2+1$ daire kullanımında çalışma ve/veya hobi odası gibi farklı alanlara ihtiyaç duyulabileceği göz önünde bulundurulmamıştır. Bu nedenle katılımcılar iç mekanda bireysellik için yeterince özel alan olmadığını belirtmektedirler. Toplam metrekare değerlendirildiğinde ise, bu gibi alanların sabit olacak şekilde, sonradan içeriye dahil edilmeleri mümkün değildir. Ancak mekanları yerinde dönüştürerek bu ihtiyaçlara cevap verilebilinecektir.

\section{Tartışma}

Son dönemde global ölçekte yaşıyor olduğumuz, ülkemizde de Mart 2020 itibariyle hayatımızı kademe kademe değiştirmemize neden olan pandemi, bireylerin psikolojileri üzerinde önemli etkiler oluşturmuş̧tur. İnsanlar, evlerinde karantina sürecini yaşamış, salgın değerleri arttıkça karantina süreçleri tekrar etmiştir. Türkiye'de karantinalar belirlenen bazı günler için uygulanmış olup, bu günler haricinde kişilerin sorumluluğunda kişisel karantina uygulanması talep edilmiştir.

Bu makale kapsamında yapılan anket çalışması çerçevesinde, 3.1.1. Konuta Ait Genel Bilgiler bölümünde ulaşılan yanıtlara göre, katılımcıların evde geçirdikleri sürelerin artışının belirlenmesi sonucu, rezidans sakinlerinin kişisel karantina uygulamasına uyum gösterdikleri tespit edilmiştir. Karantina uygulamasının bireyleri salgından korumak çerçevesinde pozitif bir etkisi olmasının yanında, psikolojik anlamda negatif etkileri de olmaktadır. Koçak, Z. ve Harmancı, H., uygulanan karantina ve kısıtlamalarının, alışkın olunan hayat akışının farklılaşmasına, dolayısıyla bireylerin ve ailelerin ruh sağlığının etkilenmesine neden olduğunu belirtmişlerdir. Karantina ve sosyal izolasyon 
süresi uzadıkça kaygı bozuklukları öncelikli olmak üzere, depresyon, akut stres bozukluğu, travma sonrası stres bozukluğu, somatik belirtili bozuklukların daha sık görülmesi ihtimalinin arttığını açıklamışlardır. Buna ek olarak, ev içerisinde geçirilen sürenin artması, dolayısıyla fiziksel aktivitenin evin içinde kısıtlı kalması kapsamında Tural, E., sağlıklı bireylerin dahi düşük düzeyde fiziksel aktiviteye sahip oldukları bu dönemin; sağlıkla ilişkili yaşam kalitesi, fiziksel fonksiyon, ağrı ve genel sağlık algısını etkilediğini belirtmiştir. Dolayısıyla pandemide bireylerin kendilerini yalnızca virüs salgınından değil, aynı zamanda psikolojik sağlık sorunlarının oluşmasından da korumaları gerekmektedir. Öyle ki, Aşkın, R., vd., pandemi bitse dahi psikolojik etkilerinin yıllar boyu sürebileceğini belirtmektedir. Önceki çalışmalar kapsamında da bulaşıcı hastalık salgınlarının, genel popülasyonda anksiyete, depresyon ve stres düzeylerini artırabildiğini açıklamışlardır. $\mathrm{Bu}$ anlamda, günümüzün çoğunu geçirdiğimiz evlerimizin iç mekan konforu ve ihtiyaçlarımızı karşılayabilmesi, psikolojik etkileri bertaraf edebilmemiz için oldukça önem taşımaktadır.

Bu kapsamda, öncelikle iç mekanın doğa/dış mekan ile temas alanını oluşturan balkon, teras, bahçe alanlarının rezidans kat planlarındaki yeri incelenmiştir. Yapılan anket sonuçlarına göre, rezidans sakinlerinin balkon ve hatta mümkün olduğunda özellikle bahçe ihtiyacı içerisinde oldukları tespit edilmiştir. Rezidanslar yüksek katlı binalar oldukları için, standart apartmanlara göre doğa ile daha az temas halindedirler. Bu nedenle, bu tip binalarda yaşayanların doğa ve dış hava temas ihtiyacı oldukça yüksek olmaktadır. Anket sonuçlarının değerlendirmelerinde de yer verildiği gibi, katılım yapılan rezidans projelerine de bağlı olarak katılımcıların \%52.1'i balkonu bulunduğunu belirtmiştir (Şekil 3.4). Bu orana bağlı olarak geri kalan ve katılımcıların yaklaşık diğer yarısını oluşturan grupta balkon bulunmamaktadır. Böylece balkon bulunmayan konut oranı da oldukça yüksektir. Balkon bulunması, sadece balkonun mevcut olduğu anlamına gelmekte olup, aktif kullanılıp kullanılamadığının tespit edilmesine yönelik sorulan sorularla katılımcıların \%53.5'i evlerinde açık oturum eksikliği hissettiğini, yani dış mekan temas ihtiyacının karşılanamadığını belirtmiştir. Bu oran, balkonu bulunmadığını belirten katılımcı oranından oldukça daha yüksektir ve bu durum da mevcut balkon yapılarının fiziki koşullarının incelenmesi gerekliliğine işaret etmektedir. Anket soruları içerisinde yer alan, balkon alanının tespitine yönelik soruya verilen cevaplar eşit dağılımla \%11.3'ü ortalama 1-5 $\mathrm{m}^{2}$ arası balkon alanının bulunduğunu, yine $\% 11.3$ 'ü $16-20 \mathrm{~m}^{2}$ arası balkon alanının bulunduğunu ve yine aynı oranda $\% 11.3$ 'ü $25 \mathrm{~m}^{2}$ üzeri balkon alanı bulunduğunu belirtmiştir (Şekil 3.5). Bu durumda, balkon alanlarının yetersizliği, yalnızca Fransız balkonu bulunan projeler ile, balkon sahibi katılımcıların \%11.3'ünü oluşturan ve 1-5 $\mathrm{m}^{2}$ arası balkonu bulunan grup için söz konusudur. Fransız balkon, yapısal özelliği dolayısıyla pencerelerden daha avantajlıdır fakat bir balkon deneyimi sunamamaktadır. Bu nedenle de kullanııısına dış mekan temas deneyimi yaşatamamaktadır. Benzer şekilde $1-5 \mathrm{~m}^{2}$ arası balkon alanı, kullanıcılar için yetersiz kalarak kısa bir taze hava alımı sağlamak dışında gerçek bir dış mekan temas deneyimi sunamayacaktır. Bu doğrultuda "lüks" olma koşulunu barındıran rezidans binalarında uygun yapım teknikleri ile dış mekan temas deneyimini kullanıcılarına sunabilecekleri genişlikte balkonlar yapılması gerekmektedir. Bunun haricinde ihtiyaçlar doğrultusunda, belirli bir yükseklikten sonra balkon alanlarında rüzgara karşı siperlikler ve/veya açılıp kapanabilen sistemlerin kullanımı ile yeşilin balkon içerisine dahil edilmesi, balkon kullanımının artmasına, dolayısıyla dış mekan ile temasın yüksek katlarda da artmasına çözüm olabilecektir.

İç mekandaki diğer konfor analizlerine gelince; iç mekanın bireyler üzerindeki psikolojik etkileri zaten pek çok araştırma kapsamında bilinmekteydi. Duyularımızla özümsediğimiz ve bireysel bağlamımızda algıladığımız mekanlarda kullanılan form ve malzemeler (renk, doku, desen) her bireye kendi bağlamında ve bazen genel çerçevede etki etmektedir. Örneğin, Alici, N. ve Paktaş, M., G., araştırmalarında belirttikleri gibi iç mekanda kullanılan renkler, bireyler üzerinde rengin türüne göre farklı psikolojik etkiler oluşturmaktadır. Yine aynı araştırmada belirttikleri gibi Bruno Zevi'ye göre; "Mekan; biz istesek de istemesek de bizi etkiler ve benliğimize hükmeder”. Dolayısıyla iç mekan kurgusunun ve malzeme, donatı seçimlerinin bireylerin davranışları üzerinde doğrudan etkisi olduğunu söyleyebiliriz. Tasarlanan mekanlar kullanıcılara psikolojik mesajlar vermektedir, bu durum mekanın kullanımında olumlu ya da olumsuz etkiler yaratmaktadır. Pandemi döneminde, konutlarda temas süresi ve yoğunluğunun artması ile ufak detaylar dahil büyük önem kazanmıştır. Örneğin; daha önceleri kayıp mekan olarak değerlendirilen balkonlar, anket sonuçlarından da görüldüğü gibi, nefes almak için temel bir ihtiyaç haline gelmiştir. Uzaktan çalışma sistemine geçilmesi ile birlikte ev-ofis ihtiyacı gelişmiş ve çalışma odası mahalinin evlere dahil edilmesi gerekliliği ortaya çıkmıştır. Bu tür mahallerin eksikliği, bireylerin iç mekanda konforsuzluk hissetmelerine sebep olmuştur. Makale kapsamında, rezidansların iç mekan organizasyonu alanında yapılan incelemeler doğrultusunda, dairelerin alan açısından standart apartmanlara göre daha kısıtlı olması sebebi ile mekanların açık kullanılarak daha geniş oldukları izlenimi verilmek istendiği tespit edilmiştir. Örneğin, kapısı olmayan bir mahal, yanında olduğu diğer mahal ile 
birleşerek kullanıcısında daha geniş olduğuna dair bir algı oluşturacaktır. Bu sebeple, özellikle salon mahalleri, mümkün oldukça kapısı olmayan ve giriş holü ile evin dağılımının olduğu diğer hole bağlanan bir yapıya sahip olmuştur. Böylece kullanıcılar salon mahallerinin alan kısıtını algılayamamaktadırlar. Mutfakların, yaşamın da pratikleşmesi sonucu daha basit bir kullanımı olmuştur. Klasik mutfak kullanımı anlayışı, rezidans kullanıcılarında değişmektedir. Bu sebeple mutfak mahallerinin alanlarının kısıtlanması, tasarımcılar açısından konut içi mekanda alan kazanmak üzere bir çözüm olarak görülmüştür. Bu nedenle de mutfaklar çoğunlukla salon ile aynı mahal içerisinde bulunmaktadır. Burada da mutfağın geniş bir mahal içerisinde yer alması sebebi ile kullanıcı mutfak alanının daraldığını algılayamamaktadır. Bu durum, aynı zamanda iç mekan planlamasında, günışığından faydalanamayan mutfak mahalleri için de bir çözüme dönüşmüş ve salon pencerelerinden alınan günışığı salon ile alanı ortak kullanan mutfağa fayda sağlamıştır. Bu durumda, farkına varılan ihtiyaçlara yönelik ek mahal gereksinimlerinin yaşama birimlerine dahil edilebilmesi için, metrekare bazında çok geniş olmayan bu mevcut konut binalarının, yerleşim planlarında bir dönüşüm ve yeni yapılacak konut binaları için de öneriler geliştirilmesi gerekmektedir. Ak, Ö., bu koşullarda evlerin kullanıcılarını daha önce rahatsız etmeyen hatta konforlu dedikleri özelliklerinin onları huzursuz etmiş olabileceğini belirterek, son yıllarda yaşam alanlarını birleştirmek amacıyla duvar ve kapıların ortadan kalktığı kat planları tasarımının, tüm ev halkının evde zaman geçirmek zorunda kaldığı ve herkesin ayrı, özel bir alana ihtiyaç duyduğu karantina günlerinde konforunu bir miktar da olsa yitirdiğinin üzerinde durmuştur. Bu dönemde, fazladan bir odanın, hatta birkaç metrekarenin bile öneminin farkına varıldığını anlatarak bu nedenle de daha önce açık plan ev projeleri çizen mimarların, bundan sonraki projelerinde daha fazla odaya, duvara ve kapıya yer vereceklerini düşündüğünü belirtmiştir.

Rezidans kat planlarının bir başka sorunsalı olan mahremiyet problemi de bu açık yaşam planlaması ile bağlantılı olup, anket sonuçlarında görüldüğü ve kat planları ile de desteklendiği üzere, rezidanslardaki kat planlarını çoğunlukla açık-birleşik mekan tipi oluşturmaktadır. Mullins, P., ve Robb, J., H.'nin araştırmaları sonuçlarına göre, yüksek katlı konut binalarında yaşayanlar, tekil konutlarda yaşayanlara göre yaşama mekanlarının yetersizliği ve mahremiyetle ilişkisi kapsamında, hem iç mekan hem de çevresel bağlamda doyuma ulaşamadıklarını belirtmişlerdir. Doyumun sağlanamaması bireylerin psikolojilerini ve dolayısıyla davranışlarını olumsuz etkilemektedir. Ankette katılımcılara sorulan iç mekan yerleşimi yeterince konforlu değilse sebebinin ne olduğuna dair soruya, katılımcıların \%18.3'ü "iç mekanda bireysellik için yeterli özel alan yok", \%9.9'u "iç mekanda yeterince alan yok" şeklinde yanıt vermiştir (Şekil 3.11). Bununla birlikte iç mekan yerleşimini anlamak için sorulan farklı sorularda katılımcıların \%45.1'i mutfak ve salon mahallerinin bir arada bulunduğunu, \%39.4'ü salonun girişe açık olduğunu, \%25.4'ü salonun giriş ile birleşik olduğunu, \%21.1'i, mutfağın giriş ile birleşik olduğunu, \%8.5'i banyonun giriş alanında bulunduğunu belirtmiştir (Şekil 3.8). Bu kısımda verilen yanıtlar da katılımcıların yaşadığı ve İstanbul'da yer alan diğer ulaşılabilen rezidans projelerinin kat planlarının incelenmesi sonucu oluşturulan ve bölüm 3.2 Rezidans Binalarında Kompakt Kat Planları bölümünde yer verilen, anahtar planlardaki iç mekan organizasyonlarını desteklemektedir. Günün önemli bir bölümünü kapalı mekanlarda farklı insanlarla bir arada geçiren bireyler, en özgür ve kendileri olabildikleri yegane yer olan evlerinde, kendilerini yaşayabilecekleri bir alan arzu etmektedirler. Bu talep, aynı evin içerisinde yaşayan aile bireyleri için de ayrı ayrı geçerlidir. Makale içerisinde gösterilmiş olan tip kat planlarındaki yerleşim modeli, kullanıcıların kendilerine ait mekan isteklerini karşılayamamaktadır. Mahallerin daha geniş alan hissiyatı vermek için açık planlı tasarlanması, alansal yetersizliklerden dolayı yatak odalarının giriş hacminden ayrı tutulamaması, yatak odalarına giden ayrı bir hol bulunmaması gibi tasarım özellikleri, ev içi yaşantının tamamıyla ortada ve herkese açık, paylaşılan bir hale gelmesine sebep olmaktadır. Bu durum, rezidans sakinlerinin, pandemiye kadarki dönemde sebeplerini ayırt edemeseler bile, evlerinde hissetmek istedikleri mahremiyeti yaşayamadıkları için huzursuz olmalarına ve zaman içerisinde mutsuzluklarına sebep vermektedir. Yapılmış olan ankette de kullanıcıların \%56.3'ünün rezidans binalarının iç mekan organizasyonunu çok konforlu bulmama sebebini, yüksek oranda bu mahremiyet eksikliğinin oluşturduğunu söyleyebiliriz (Şekil 3.10).

Pandemi döneminde, daha önce belirtildiği gibi zaten salgına dair yaşanan psikolojik rahatsıllıklara, iç mekan konforuna dair problemlerden kaynaklı psikolojik sorunların eklenmesi, bireylerin yaşamları açısından oldukça çözümsüz noktalara ulaşabilecektir. Pek çok araştırmanın sonucuna göre, bu makalede de sonuç olarak varıldığı gibi, uzunca bir süre karantinada kaldıktan sonra, bir kişiden daha fazla bireyin paylaştığı konutlarda, mahremiyet kavramı oldukça değer kazanmıştır. Bu kapsamda, kullanıcıların daha önce evlerinde öncelik olarak algıladıkları unsurlarda temel değişiklikler olmuştur. Örneğin; bireysel hobi alanları, yalnız kalma ve dinlenme gibi ihtiyaçların karşılanabileceği özel hacimlere duyulan gereksinim ortaya çıktı. Mevcut kat planlarında ihtiyaçtan ziyade, tüketim odak olduğu için açık bir yerleşim modelini içeren kompaktlık mevcut idi. Dolayısıyla Pardorokes, B.G.'nin de 
araştırmasında belirttiği gibi, son yılların iç mekan düzenlemelerinde önemli oranda ön planda olan açık planların artık kullanılmayacak olduğu düşünülmektedir. Mutfak-oturma-yemek-çalışma odalarının bir arada olduğu büyük açık alanların, özellikle böyle dönemlerde işlevsiz olduğu görüldü. Tüm bireylerin az da olsa, rahatsız edilmeyeceği, kendi özel alanlarına ihtiyaçları olduğu hatırlandı. Yine bu konuda, mevcut planların içerisine dahil edilebilecek parazit mekanların kurgulanabileceği de tartışılmaktadır. Bu tür mekanların özellikle çalışma odaları gibi ek birimler için değerlendirilebileceği düşünülmektedir (Aşkın, S.).

\section{SONUÇ:}

Lüks yüksek katlı konut binalarının karşılığ etse de yapımı giderek artış göstermektedir. $\mathrm{Bu}$ artışın sebepleri, hem yer aldıkları metropollerde, kent merkezlerindeki arsa fiyatlarının yükselmesi, hem de nüfus artışı sebebi ile daha fazla kişiyi daha az alan içerisinde yerleştirebilmenin çözümü olarak dikey mimarinin ön plana çıkmasıdır. Tüm bunların yanında, hitap ettiği düşünülen kesim özellikle konfor ve prestij amaçlı olarak bu binalara yönelmekte, ancak sonrasında bazı problemler yaşamaktadır. Konfora yönelik problemler, pandemiye kadar çoğunlukla iç mekan yerleşimi ile ilgili olup, konut içerisinde geçirilen süreler kısıtlı olduğu için üzerinde durulmuyordu. Fakat pandemi ve sonrası değişen yaşam koşulları ile hem önceden dikkat çeken bu problemler daha büyük önem kazanmış, hem de özellikle dış mekan teması ile ilgili olarak başka problemler eklenmiştir. Bu makale de bu problemlerin ortaya konulabilmesini amaçlamıştır.

İnsan her zaman doğa ile mümkün oldukça iç içe olmak ister. Ancak yaşantısının büyük çoğunluğunu kapalı mekanlarda geçirdiği için bir kapalı mekandan bir başkasına giderken ancak temas ettiği dış hava ile bu ihtiyacını tatmin etmeye çalışır. Metropollerde yaşamın yorucu olma sebeplerinden bir tanesi de bu temas eksikliğidir. Pandemi döneminde ve sonrasında kapalı mekan kullanımının artması ve tek mekanda daha uzun vakit geçirilmesi ile dış mekan temas ihtiyacı daha da artmış bulunmaktadır. Makalede de yer verildiği gibi, aynı mekanda uzun süre kapalı bulunma ve karantina sürecinin getirdiği yalnızlık çerçevesinde, kişiler çeşitli psikolojik problemler ile karşı karşıyadır. Bu bağlamda, dış temas ve taze hava alımı oldukça önem kazanmış bulunmaktadır. Dolayısıyla, önceleri konut projelerinde, alandan kısan bir eklenti olarak görülen balkonların yapımı, yeniden değerlendirilmektedir. Makale kapsamındaki incelemeler sonucunda, kullanıcıların balkon kullanımına verdikleri yanıtlar çerçevesinde, ilk olarak rezidanslarda balkon alanlarının $5 \mathrm{~m}^{2}$ üzeri yapımı önerilmektedir. Diğer bir konu ise, rezidans binalarının yüksek katlı yapıları nedeniyle, iklimsel konfor koşullarının balkonlarda sağlanamaması sebebi ile uygun genişlikte olsalar dahi balkonların kullanılamıyor olabileceğidir. Bu kapsamda en temel problem rüzgardır. Araştırmalar doğrultusunda özellikle 10. kattan sonra rüzgar yüklerinin artması ile hakim rüzgar yönü baz alınarak tasarlanmamış olan balkonların kullanılması mümkün olamayacaktır. Binalarda yerleşimlerin daire tipine göre yapıldığını düşünürsek, dış mekan ile temas alanlarının temel alınarak yerleşimlerin yapılmadığını öngörebiliriz. Bu durum, ticari açıdan bir gereklilik olup benzer kat planlarının her katta belirli bir şekilde dağılımı gerekliliğini bozmadan bir çözüm önerisi getirilmelidir. Bu doğrultuda önerilebilecek en uygun çözümler, hakim rüzgar yönünün avan proje aşamasında tespiti ve basit simülasyonlar ile bu yönde siper görevi görmek üzere cephe elemanları yerleştirilmesidir. Sadece rüzgar yüküne karşı çalışacak bu elemanların tüm balkon alanını kapatması gerekmemektedir. Bu şekilde bir korunak sağlandıktan sonra 10. kat üzerinde yapılacak balkonlar da aktif bir şekilde kullanılabilecektir.

Anket sonuçlarına göre bir başka temel ihtiyaç ise yeşildir. Bahçe talebinin oransal yüksekliği bu bulguyu doğurmaktadır. İçeriğinde "konfor" kavramını kullanıcısına hedef olarak sunan bu bina tipolojisinde, yeşili barındırmak da mümkündür. Günümüzde yeşil, artık sadece zemin seviyesinde ve yatayda değil, her yükseklikte ve hatta dikeyde dahi yer alabilmektedir. Bu doğrultuda, daireler için tasarlanacak olan balkonlarda, projenin konseptine uygun olacak şekilde, bitki yetiştirmeye de elverişli alanlara yer verilmesi bir çözüm olabilecektir. Bu alanlar balkon hattı boyunca, kenarlarda, tek bir yönde, vb. gibi tasarıma göre şekillenebilecektir. Böylece her daire sakini balkonunda dış mekanla temas ettiği gibi, doğa ile de temas edebilmiş olacaktır. Bir önceki öneride belirtildiği gibi rüzgar yüklerine karşı önlemler alınması, bu öneri için de geçerlidir, böylece istenilen yeşil örtü de korunabilecektir.

Dış mekan teması arzusu ve doğa özleminin yanında pandemi öncesinden beri süregelen, rezidanslara ait iç mekan konforuna yönelik problemler, konutlarda geçirilen sürenin artması ile daha büyük önem kazanmıştır. Rezidanslar daha küçük alanda, daha konforlu ve lüks bir yaşantı ihtiyacı doğrultusunda ortaya çıkmışlardır. Bu sebeple de iç mekan yerleşiminde kompakt bir tasarım modeline uyulmaktadır. İstanbul içerisinde yer alan rezidans projelerinin erişilebilen tüm kat planları incelenmiş ve bu araştırma kapsamındaki kat planları, bu incelemenin bir özeti olarak 
oluşturulmuştur. Bu kat planlarında da sözü geçen kompakt açık yerleşim tipi net bir şekilde görülebilmiştir. Bu yerleşim tipinin, bir diğer götürüsü de mahremiyetin bireysel bağlamda sağlanamamasıdır. Bu durum da, araştırmalar doğrultusunda, rezidans sakinlerinin en öndeki sıkıntısıdır. Pandemi döneminin oluşturacağı psikolojik problemlerin dışında, ek psikolojik problemler oluşmasına neden olabilecektir.

Bu planlamanın yerinde dönüşümünü, ancak esnek mekan sistemleri gibi sonradan yapılabilecek eklemeler ile sağlamak mümkün olabilir. Bireyselliğin yaşanabileceği en mahrem birim olan evlerde, kişinin kendiliğini yaşayabileceği alanlara ihtiyacı bulunmaktadır. Aslında, pandemi öncesinde de kat planlarında yer alan odaların, yalnızca yatak odası olması dışında başka fonksiyonel oda alanlarına ihtiyaç vardı. Ancak, dış mekanlarda geçirilen vakitlerin uzunluğu, trafik yoğunluğu sebebi ile dişarıda geçirilen vaktin uzunluğu ve yorgunluk gibi sebeplerle "ev"lerin daha çok konaklama amaçlı kullanımı söz konusu idi. Konaklama amaçlı olsa dahi barındırdığı anlam dahilinde "ev" yine de en mahrem olunan alanı işaret ediyordu. Fakat süre kısıtı sebebi ile problemlerin üzerinde çok durulmuyordu. Pandemi ile evde geçirilen sürenin artması, bu problemlere yanıt arama ihtiyacını doğurdu. Aynı zamanda, pandeminin oluşturabileceği psikolojik problemlere, iç mekan kaynaklı psikolojik problemlerin de eklenmemesi, tam tersine iç mekanda yaşanacak konforun bireylerin ruh salığını iyileştirici nitelikte olması gerekmektedir. Dolayısıyla, yeni yapılacak rezidans planlarında bu koşullar göz önünde bulundurularak alan kullanımının arttırılması ya da mekanların dönüştürülebilir olarak tasarlanması gerekmektedir. Mevcut konutlarda ise bu dönüşüm, esnek yapı elemanları ve/veya mobilyalar ile yapılacak renovasyonlarla sağlanabilecektir. Böylelikle çalışma odası, mahrem yatak odası alanları, hobi odaları, bireysel dinlenme birimleri gibi alanlar dairelerin içerisinde yer bulabilecektir.

Rezidanslar daha küçük alanlar içerisinde daha konforlu ve lüks bir yaşantı sunmayı temin ederken, mahremiyetin "ev" kapsamındaki yerini ve insan psikolojisi üzerindeki etkisini atlamamalıdırlar. Bu doğrultuda, hedef yalnız güncel ve kaliteli malzemelerin kullanımı ile belirtilen oda sayılarına ulaşmak olmamalıdır. İç mekan organizasyonunda mahaller aktivite özelliklerine göre birbirlerinden ayrılmalı ve özellikle kullanıcılara özel alan sunmak üzere giriş bölümünden ayrı tutulmalıdırlar. Bu bağlamda, rezidansların nitelikleri gereği alanlar arttırılmadan çözüm önerileri sunmak önemlidir. Bu sebeple sunulabilecek öneriler içerisinde iç mekan formları üzerinde çalışmak, mekanları yapı elemanları yerine dekoratif niteliği de olan bölücüler ile ayırmak, lüks olmayı hedefine yerleştirmiş bu bina tipolojisine oldukça uygun bir çözüm olarak makale bütününde de önerildiği gibi esnek mekan önerileri geliştirmek sayılabilir. Anket çalışmasının sonuçlarından da anlaşıldığı üzere rezidans sakinleri, bu bina tipolojisini tercih etmekten memnunlar. Ancak iç mekan konforuna dair bazı eksiklikler mevcut. Rezidans binaları lüks ve konforu bir arada bulundurmayı temin eden ve en güncel yapım teknikleri ile inşa edilen binalar oldukları için geliştirilmeye oldukça açık bir yapıdadırlar. Uygulanması mümkün olabilecek, önerilen tasarım modelleri gerçekleştirilebilecektir. Bu makale kapsamında, kullanıcılarının geri dönüşleri ve örnek proje incelemeleri ile gerçekleştirilen, rezidans binalarında hedef olan lüks ve konforu artırmaya yönelik öneriler, değerlendirilerek yeni yapılacak olan projelere katkı sağlayabilecektir.

\section{Etik Standart ile Uyumluluk}

Çıkar Çatışması: Herhangi bir çıkar çatışması bulunmamaktadır.

Etik Kurul İzni: Bu çalışma için etik kurul iznine gerek yoktur.

Finansal Destek: Bulunmamaktadır.

\section{KAYNAKÇA:}

Ak, Ö., (2020). Pandemi Mimarisi, TÜBİTAK Bilim ve Teknik Dergisi, Ağustos 2020: 32-45.

Alici, N., Paktaş, M., G., (2020). İç Mekanda Renk Algısı ve Psikolojiye Etkileri, Modular Journal, 3(1): 89-105. 
Aşkın, R., Bozkurt, Y., Zeybek, Z., (2020). COVID-19 Pandemisi: Psikolojik Etkileri ve Terapötik Müdahaleler, İstanbul Ticaret Üniversitesi Sosyal Bilimler Dergisi Covid-19 Sosyal Bilimler Özel Sayıs1, 37 (Bahar Özel Ek): 304-318.

Aşkın, S., (2020). COVID-19 Sonrası Konut, Erişim Adresi: https://manifold.press/covid-19-sonrasi-konut

Atmaca, M., Yılmaz, A., Z., (2016). Türkiye’de Otel Binaları için Optimum Enerji ve Maliyet Etkinliğinin Belirlenmesine Yönelik Uygulama Örneği, Beykent Üniversitesi Fen ve Mühendislik Bilimleri Dergisi; 9 (2): 1-27.

Aydın, D., Mıhlayanlar, E., (2017). Yüksek Konut Yapılarında İç Ortam Kalitesinin İncelenmesi, Megaron; 12 (2): $213-227$.

Bilgin, N., (1990). Fiziksel Mekandan Insani ya da Insanlı Mekana, Mimarlık; 3: 62-65.

Dikmen, Ü. S., Yiğit, S., Aksel, M., Sönmez, M., Şener, B., (2011). Yüksek Yapı Çalışmalarında Bir Verimlilik Faktörü: Rüzgar, 6. İnşaat Yönetimi Kongresi, Bursa TMMOB İnşaat Mühendisleri Odası, pp.370-384.

Göregenli, M., (2018). Çevre Psikolojisi İnsan-Mekan İlişkileri, İstanbul Bilgi Üniversitesi Yayınları.

Güzelci, H., (2018). İstanbul'un Değişim Sürecinde Konut Reklamlarının Göstergebilimsel Çözümlemesi: 2000 Sonrası Mimari Örnekleri, The Turkish Online Journal of Design Art and Communication, Vol. 8, Issue 1, pp. 45-60.

Hariri, N., (2016). Natural Ventilation Integration in Residential High-Rise Buildings in Hot and Humid Climates: Shafts Influence, Cardiff University The Welsh School of Architecture.

Hasol, D., (2016). Mimarlık Cep Sözlüğ̈̈, YEM Yayın.

Koçak, Z., Harmanc1, H., (2020). COVID-19 Pandemi Sürecinde Ailede Ruh Sağlı̆̆l, Karatay Sosyal Araştırmalar Dergisi, 5: 183207.

Mullins, P., Robb, J., H., (1977). Residents' Assessment of a New Zealand Public-Housing Scheme, Environment and Behavior, 9: 573-624.

Omrani, S., Garcia-Hansen, V., Dorgemuller, R., Capra, B., (2016). Thermal Comfort Evaluation of Natural Ventilation Mode: Case Study of a High-Rise Residential Building, 50 ${ }^{\text {th }}$ International Conference of Architectural Science Association 2016, pp. 1-9, The Architectural Science Association and The University of Adelaide.

Pardorokes, B., G., (2020). Pandemi Sonrası Mimari ve Evlerimiz: Mimari Anlamda Öne Çıkan 7 Konu, Erişim adresi: https://www.uplifers.com/pandemi-sonrasi-mimari-ve-evlerimiz-mimari-anlamda-one-cikan-7-konu/

Sadıkoğlu, H., Özsoy, A., (2016). Üst Gelir Grubu Konut Tercihi Olarak Rezidans Kullanımı, İdealKent, ISSN: 1307-9905, Say1 18 , Cilt 7, 226-245.

Sönmez, A. L., (2010). Nitelikli Servisli Konutların (Residence) Sosyo-Kültürel Sürdürülebilirlik Boyutunun Kullanıcı Açısından Incelenmesi: Levent Loft Örneği, Yüksek Lisans Tezi, İstanbul Teknik Üniversitesi Mimarlık Fakültesi.

Taşç1, G., (2017). A New Approach to Increase Energy Efficiency of Luxury High-Rise Residential Buildings through an Advanced Facade Component, Doktora Tezi, İstanbul Teknik Üniversitesi Mimarlık Fakültesi.

The Skyscraper Center, (2020). Global Tall Building Database of the CTBUH (Council on Tall Buildings and Urban Habitat), Erişim adresi: https://www.skyscrapercenter.com/

Tural, E., (2020). COVID-19 Pandemi Dönemi Ev Karantinasında Fiziksel Aktivite Düzeyinin Yaşam Kalitesine Etkisi, Van Sağlık Bilimleri Dergisi, 13 (Özel Sayı): 10-18.

Yılmaz, A. Z., Akgüç, A., Gali, G., Ganiç Sağlam, N., Ashrafian Bonab, T., (2015). Binalarda Maliyet Optimum Enerji Verimliliği Seviyesi için Türkiye Koşullarına Uygun Yöntemin ve Referans Binaların Belirlenmesi, TÜBİTAK 1001. 